\title{
NOTES
}

\section{The Extraterritorial Effect of Criminal Convictions}

"The Courts of no country execute the penal laws of another. . . ."1 Thus Chief Justice Marshall phrased a fundamental doctrine which has been universally recognized. ${ }^{2}$ And since the "full faith and credit" clause of the Federal Constitution ${ }^{3}$ applies only to civil judgments, ${ }^{4}$ it might be thought that criminal convictions should have no effect whatever upon the convict, by way of civil disability, except in the jurisdiction wherein the conviction was rendered. But this result has by no means always been reached.

Suppose, for example, that State $X$ does not permit a person convicted of felony to hold public office. If a man convicted of felony in State $Y$ is deprived of his office in State $X$, can it be said that State $X$ is attempting to enforce the penal laws of State $Y$ ? Some courts consider the disabilities as part of the penal judgment, ${ }^{5}$ hence unenforcible extraterritorially. Others reach a contrary result by reasoning that disqualifications are not part of the judgment of conviction, but mere consequences which flow from it. ${ }^{6}$ It has been pointed out that ineligibility is imposed upon the convict, not for the purpose of punishing him but because, by the commission of a crime, he has shown himself a person unworthy of trust, and also in order to protect the public. ${ }^{7}$ An interesting, but not very enlightening, distinction was sought to be drawn by one judge between denial of a privilege never enjoyed and denial of a right previously conferred. ${ }^{8}$

There is also a division of authority as to what event gives rise to the disabilities. In giving extraterritorial effect to criminal convictions it has sometimes been declared that the commission of the crime, and not the conviction therefor, works the disqualification, the judgment of conviction being conclusive evidence of its commission. ${ }^{9}$ On the other hand, a foreign conviction has been held not to disqualify, on the ground that the conviction, and not merely the commission of the crime, disqualifies the convict, ${ }^{10}$ and the

I. The Antelope, ro Wheat. 66, I23 (U. S. I825).

2. Banco de Vizcaya v. Don Alfonso de Borbon y Austria, [1935] I K. B. I40; see Wisconsin v. Pelican Ins. Co., I27 U. S. 265,289 (1888); Huntington v. Attrill, I46 U. S. 657, 669 (1892); Huntington v. Attrill, [r893] A. C. I50, I56; ResTateMENT, CoNFLICT OF LawS (I934) § 427; GOODRICH, CONFLICT OF LAWS (I927) \&8.

3. U. S. Consr. Art. IV, §I.

4. Commonwealth v. Green, I7 Mass. 515 (I822); Sims v. Sims, 75 N. Y. 466 (I878). Contra: Chase v. Blodgett, ro N. H. 22 (I838) semble; State v. Candler, 3 Hawks 393 (N. C. I824) semble.

5. See State v. Grant, 79 Mo. II3, I22 (I883) ; Sims v. Sims, 75 N. Y. 466, 469 (I878).

6. State v. Jones, 82 N. C. 685 (I880); see State ex rel. Attorney General v. Irby, 81 S. W. (2d) 4I9, 423 (Ark. I935); McKannay v. Horton, I5I Cal. 7II, 720, 9I Pac. 598, 60I (1907); Chase v. Blodgett, Io N. H. 22, 29 (I838); State ex rel. Olson v. Langer, $256 \mathrm{~N}$. W. 377,387 (N. D. 1934).

7. Ex parte Brounsall, 2 Cowp. 829 (K. B. 1778 ) ; see Ex parte Wall, 107 U. S. 265,288 (1883) ; Anderson v. Baker, 23 Md. 53I, 607 (I865); Chase v. Blodgett, Io N. H. 22, 29 (I838). But cf. In re Green, 49 P. (2d) I97 (Okla. I935).

8. Weisel, $\mathrm{J}$., in Anderson v. Baker, 23 Md. 53I, 608 (1865).

9. State v. Candler, 3 Hawks 393 (N. C. I824); State ex rel. Olson v. Langer, 256 N. W. 377 (N. D. 1934).

Io. Sims v. Sims, 75 N. Y. 466 (I878) ; I GREENLEAF, Evidence (I6th ed. I899) § 375 ; I WIGMORE, EUTDENCE (2d ed. rg23) § 521 . 
conviction being inoperative except within the jurisdiction where rendered, the disabilities consequent thereon are to be similarly limited. It will thus be seen that there are two distinct lines of thought on this problem. The particular type of disability involved determines, to a large extent, which line of reasoning is applied, and consequently whether the criminal conviction will or will not be given extraterritorial effect.

At common law a person was incompetent as a witness if he had been convicted of an infamous crime. ${ }^{11}$ In I 822 it was decided in the case of Commonwealth v. Green ${ }^{12}$ that a conviction in another state did not disqualify a witness in Massachusetts. The court based its decision upon (I) the principle that penal laws have no extraterritorial effect, (2) the difficulty of authenticating the record of the foreign judgment, (3) the variation of definitions of specific crimes in different jurisdictions, and (4) the difficulty of obtaining a pardon after the convicted man leaves his former state of domicile. This case has been followed in the majority of jurisdictions, ${ }^{13}$ although there is contrary authority. ${ }^{14}$ Where the disability has been enacted into statute, the common law majority rule is followed, ${ }^{15}$ unless the statute specifically provides otherwise. ${ }^{16}$

In attempting to evaluate the doctrine of Commonwealth v. Green it is well to bear in mind that the old common law disqualification was likely to result in injury to innocent parties. It was never popular with the judiciary, ${ }^{17}$ nor with the modern textwriters, ${ }^{18}$ and has been largely abrogated by statute. $^{19}$ It is therefore natural that courts limit its application whenever possible. $^{20}$

Those jurisdictions which adhere to the rule of Commonwealth $v$. Green have the further question to face: should the foreign conviction be admitted into evidence for the purpose of impeaching the witness? Some

Ir. Pendock d. Mackender v. Mackender, 2 Wils. I8 (I755); x GReEnLEaf, Evinence (I6th ed. r899) \$372; 5 Jones, EVIDENCE (2d ed. I926) \$20g6; I WigMore, EVIDENCE (2d ed. I923) \& 519 .

I2. I7 Mass. 515 ( 1822 ).

13. Logan v. United States, I44 U. S. 263 (I892); Langdon v. Evans, 3 Mackey I (D. C. I883); I GREENLEAF, EVIDENCE ( 16 th ed. I899) \$376; 5 Jones, Evidence (2d ed. I926) $\$ 2098$; I Wigmore, Evidence (2d ed. I923) \$522; Notes L. R. A. I9I7A II38; (I907) 5 ANN. CAS. 917.

It is doubtful whether a party may deliberately take advantage of this rule in a suit upon a transitory cause of action. In Weaver v. Alabama Southern R. R., 200 Ala. 432, 435, 76 So. 364,367 (I917), Sommerville, J., said: “. . . if the law of Georgia, contrary to the law of Alabama, disqualified from testifying the only witness by whom complainant could establish its defense, respondent's resort to a Georgia court, in order to suppress the testimony of that witness, would be . . . unfair, and the result . . . perversive of justice. . ."

I4. State v. Foley, I5 Nev. 64 (1880); Chase v. Blodgett, Io N. H. 22 (1838) ; State v. Candler, 3 Hawks 393 (N. C. I824).

I5. State v. Landrum, I27 Mo. App. 653, I06 S. W. IIIr (I908); Weber v. State, I8 Okla. Cr. 42I, I95 Pac. 5Io (Ig2I) ; Samuels v. Commonwealth, IIo Va. 90I, 66 S. E. 222 (I909); Note L. R. A. I9r7A II38, II 45.

I6. Pitner v. State, 23 Tex. App. 366, 5 S. W. 2ro (I887).

17. Mitchell, $J$, speaking for the court in Diehl v. Rodgers, I69 Pa. 3I6, 324, 32 Atl. 424, 427 ( 1895 ) said: "Suppose Iindsay was the only witness to a murder, must justice be baffled because of his disability?" See also the opinion of Clarke, J., in Rosen v. United States. 245 U. S. 467 (I9I8) at p. 47 I.

18. Appleton, EVtDence (1860) 30-40; I Greenteaf, Evidence (I6th ed. r899) \$378a; 5 Jones, EVIDENCE (2d ed. 1926) \$ 210I; I WrgMoRe, EVIDENCE (2d ed. I923) § 5 I9.

19. E. g., Kan. Rev. Stat. AnN. (rg23) §62-I424; Mo. Stat. Ann. (1932) tit. 6, c. 8, § I752; N. Y. Penal Law (I916) \$ 2444 ; 6 \& 7 VICT., c. 85 (1843).

20. See (r935) 48 HaRv. L. REv. 687. 
courts permit this, ${ }^{21}$ but hold that the conviction is not conclusive as to the guilt of the witness. ${ }^{22}$ Others exclude entirely any evidence of the conviction. ${ }^{23}$ Since the record of conviction is evidence of the commission of a particular crime, it would seem that the latter view' is more consistent with the rule of evidence that the character of a witness 'for truth can be impeached by general evidence only. ${ }^{24}$ Moreover, permitting the introduction of the record while denying its conclusive effect permits the injection of a collateral issue of fact, $i$. e., whether the witness was or was not guilty of the crime for which he was convicted in the foreign state.

Likewise, at common law, a juror could be challenged for cause if he had been convicted of an infamous crime. ${ }^{25}$ In line with the cases concerning witnesses, there is some authority that conviction in a foreign state does not disqualify a juror. ${ }^{26}$ But the majority of cases are contra. ${ }^{27}$ These decisions may be explained by the self-evident fact that an act is no less infamous because it was committed across the state border. Exclusion of a juror does not hamper innocent parties, which may explain why courts are more likely to give extraterritorial effect to foreign convictions when jurors are involved, than when the disability is attempted to be imposed upon a prospective witness.

Quite different considerations obtain when courts construe statutes providing that attorneys either may or must be disbarred for conviction of a felony. Almost universally, conviction of a felony in a foreign jurisdiction is held to be within the purview of such statutes, ${ }^{28}$ although a microscopic minority dissents. ${ }^{29}$ Also, failure of a prospective attorney, when applying for admission to the bar, to disclose a previous conviction in another state is held to constitute fraud for which his license to practice may be revoked. ${ }^{30}$ It would appear that the prospect of permitting a convict to practice law has forced the judiciary to rebel against the doctrine of the strictly local effect of criminal convictions. In support of this position, the courts are bolstered by their "inherent" power to disbar for misconduct, wherever perpetrated. ${ }^{31}$

2r. Commonwealth v. Knapp, 9 Pick. 496 (Mass. I830) ; State v. March, I Jones L. 526 (N. C. 1854 ).

22. Sims v. Sims, 75 N. Y. 466 (1878).

23. Missouri, etc., Ry. v. De Bord \& Lakey, 2I Tex. Civ. App. 69r, 53 S. W. 587 (I899);

Uhl v. Commonwealth, 6 Grat. 706 ( $\mathrm{Va}$. I849).

24. See Chase v. Blodgett, Io N. H. 22, 24 (I838).

25. 3 Bi. Comm. *363.

548 (1903).

26. Queenan v. Territory of Oklahoma, II Okla. 26I, 7I Pac. 2I8 (IgoI), aff'd, I90 U. S.

27. Amaya v. State, 87 Tex. Cr. App. r60, 220 S. W. 98 (1920); Hughes v. State, I05 Tex. Cr. App. 57, 284 S. W. 952 (I926).

28. See authorities collected in State ex rel. Sanford v. Riddle, 2I3 Ala. 430, I05 So. 259 (1925); Notes (1932) 79 A. L. R. 38; (I910) I7 ANn. Cas. 599; (I909) I9 L. R. A. (N. S.) 892 . (I866).

29. In re Ebbs, I50 N. C. 44, 63 S. E. 190 (Ig08) ; cf. Ex parte Quarrier, 2 W. Va. 569

30. In re Mash, 28 Cal. App. 692, I53 Pac. 96r (I915) ; People ex rel. Deneen v. Gilmore, 214 Ill. 569,73 N. E. 737 (I905).

3x. Ex parte Wall, I07 U. S. 265 (I883); Wernimont v. State ex rel. Little Rock Bar Ass'n, Ior Ark. 210, I42 S. W. I94 (I9II); In re Simpson, 9 N. D. 379,83 N. W. 54I (I900); In re Egan, 22 S. D. 355, II7 N. W. 874 (Ig08); State ex rel. Hardin v. Grover, 47 Wash. 39, 9I Pac. 564 (I907). 
A similar rule has been adopted in respect to statutes, ${ }^{32}$ permitting revocation of the license of a physician or surgeon for conviction of crime. ${ }^{33}$ In this situation, the interest of the public is extremely vital, and the state in the exercise of its police power may fortify and protect its citizens. ${ }^{34}$

Several cases have held that where a statute in general terms excludes from the office of executor anyone convicted of crime, it does not exclude those convicted of crime in other jurisdictions. ${ }^{35}$ These decisions cite Commonwealth v. Green with approval, and follow the reasoning of that authority, at the same time distinguishing the disbarment proceedings as cases which require different treatment.

Conviction of crime was not a ground for divorce at common law, ${ }^{36}$ but has been made so by statute in most states. ${ }^{37}$ However, conviction outside the state is not a cause for divorce, ${ }^{38}$ unless otherwise expressed in the statute. $^{39}$ This is in accord with the well known dogma that statutes in derogation of the common law must be strictly construed.

In one case, ${ }^{40}$ a statute provided that no person convicted of having taken the life of another may inherit from such person. Complainant caused the death of her husband in another state, and was there convicted of the crime. The court permitted complainant to inherit from her husband, holding that the statute, being penal in nature, ${ }^{41}$ applies only to conviction within the state. This extreme decision is the only case found involving such a factual situation. It is all the more surprising when it is realized that, without the aid of a statute, some courts deny recovery to the killer, ${ }^{42}$ or at least construct a trust upon the decedent's property coming into the

32. A collection of such statutes will be found in the footnotes to Hawker v. New York, I70 U. S. 189 (1898).

33. White v. Andrew, 70 Colo. 50, x97 Pac. 564 (I92I); Seitz v. Ohio State Medical Board, 24 Ohio App. I54, I57 N. E. 304 (1926); see State Board of Medical Examiners v. Friedman, 150 Tenn. 152, 180, 263 S. W. 75, 83 (I923).

34. Meffert v. State Board of Medical Registration, $66 \mathrm{Kan} .710,72$ Pac. 247 (I903), aff'd, I95 U. S. 625 (I904) ; Lawrence v. Board of Registration, 239 Mass: 424 , I32 N. E. 174 (I92I).

35. Garitee v. Bond, 102 Md. 379, 62 Atl. 63I (Ig05); In re Canter's Estate, I46 Misc. I23, 26I N. Y. Supp. 872 (Surr. Ct. I933).

36. Note (1896) 3I L. R. A. 5 I5.

37. For a collection of statutory provisions, see Notes (I8g6) 31 L. R. A. 515;65 Am. Dec. 708 .

38. Leonard v. Leonard, I51 Mass. I5I, 23 N. E. 732 (I890) ; Martin v. Martin, 47 N. H. 52 (1866); Klutts v. Klutts, 5 Sneed 423 (Tenn. 1858); I Bishop, Marriage \& Drvorce (6th ed. I88I) \$823; Note (I896) 3I L. R. A. 5I5, 5I9. But see Johnson v. Johnson, I Walk. Ch. 309, 312 (Mich. 1843).

39. E. g., PA. STAT. Ann. (Purdon, I930) tit. 23, $\S$ Io (h). For construction of this type of statute, see Frantz v. Frantz, II Pa. Co. 467 (1892) (divorce denied); Singleton v. Singleton, 24 Pa. Dist. 667 (rgr4) (divorce granted); Bossard, Drvorce IN PENNSYLvania (1922) 93 .

40. Harrison v. Moncravie, 264 Fed. 776 (C. C. A. 8th, 1920), appeal dismissed, 255 U. S. 562 (r92x).

4I. Such a statute is not generally considered as penal. Price v. Hitaffer, I64 Md. 505, I65 At1. 470 (1933) ; Perry v. Strawbridge, 209 Mo. 62I, I08 S. W. 64I (Ig08) ; Box v. Lanier, II2 Tenn. 393, 79 S. W. 1042 (1903). Contra: Wall v. Pfanschmidt, 265; I1l. I80, I06 N. E. 785 (I9I4) semble; Kuhn v. Kuhn, I25 Iowa 449, IoI N. W. I5I (I904); Owens v. Owens, I0o N. C. 240,6 S. E. 794 (I887) semble.

42. Perry v. Strawbridge, 209 Mo. 621, I0\& S. W. 64I (I908); Shellenberger v. Ransom, 3I Neb. 6I, 47 N. W. 700 (1891) ; Riggs v. Palmer, Ir5 N. Y. 506, 22 N. E. I88 (I889); Box v. Lanier, II2 Tenn. 393, 79 S. W. I042 (1903). Contra: McAllister v. Fair, 72 Kan. 533, 84 Pac. rr2 (I906); Owens v. Owens, Ioo N. C. 240, 6 S. E. 794 (I887); Carpenter's Estate, I70 Pa. 203, 32 Atl. 637 ( I895). 
killer's hands by reason of the homicide, ${ }^{43}$ no matter where the homicide occurred.

In another case, ${ }^{44}$ a police pension fund had been established, and the rules disqualified from participation therein any police officer discharged for conviction of a felony. Relator was convicted of a felony in another jurisdiction, and discharged from the police force. The pension trustees refused to permit him to participate in the fund, and he instituted a mandamus action. The court denied the writ, saying: "Certainly it [the rule] has reference to the conviction of a felony in any jurisdiction.

Most states, either by constitution or statute, exclude from suffrage those convicted of certain serious offenses. Although no direct holding has been found, there are several dicta ${ }^{46}$ to the effect that conviction of felony in another jurisdiction works a disability, unless the statute can reasonably be construed to provide otherwise. ${ }^{47}$ It has been suggested that disqualification as to voting is a purely internal matter, ${ }^{48}$ but these expressions gave no recognition to that argument.

The closely related problem of the effect of a foreign conviction upon eligibility to hold public office has given the courts some difficulty. One early case declared, by way of dictum, that conviction of crime in a foreign jurisdiction did not disqualify an alderman under a statute which provided that those convicted of crime were ineligible to hold office; ${ }^{49}$ another left the question open. ${ }^{50}$ But since 1900 all the cases, ${ }^{51}$ with two exceptions, ${ }^{52}$ have gone the other way. These more recent decisions are in line with the purpose of the disqualification-that only those fit to be trusted should hold public office ${ }^{53}$-and it matters little where the conviction occurred. They run counter, however, to the proposition that disqualifying statutes should be strictly construed..$^{54}$

43. Sherman v. Weber, II3 N. J. Eq. 45I, x67 Atl. 5 I7 (I933); (I933) 82 U. of PA. L. Rev. I83; Bryant v. Bryant, I93 N. C. 372 , I37 S. E. I88 (I927).

44. State ex rel. Beckman v. Bowman, 38 Ohio App. 237, I75 N. E. 89r (1930).

45. Id. at p. 242, I75 N. E. at 892 . In State $e x$ rel. Little v. Selby, 22 Ohio Law Rep. 4 Io (I924), it had been determined that the trustees of the police relief fund have discretion which is not subject to judicial review. However, it is extremely doubtful whether this fact influenced the decision in the Bowman case.

46. See United States v. Barnabo, Fed. Cas. No. 14,522, at roo8 (S. D. N. Y. I876); Cowan v. Prowse, 93 Ky. I56, I7I, I9 S. W. 407, 4II (1892) ; Jones v. Board of Registrars, 56 Miss. 766,770 (I879).

47. United States v. Barnabo, Fed. Cas. No. I4,522 (S. D. N. Y. I876).

48. See (I935) 2 U. of CHI. L. Rev. 333, 334 .

49. See Hildreth v. Heath, I Ill. App. 82, 87 (I878) ; cf. State v. Du Bois, 88 Tenn. 753, I3 S. W. I088 (I8g0).

50. Gandy v. State, ro Neb. 243,4 N. W. IoIg (I880).

5I. Irby v. Day, I82 Ark. 595, 32 S. W. (2d) I57 (1930) ; State ex rel. Attorney General v. Irby, 81 S. W. (2d) 419 (Ark. I935); State v. Redman, x83 Ind. 332, rog N. E. I84 (1915) ; Crampton v. O'Mara, I93 Ind. 55I, I39 N. E. 360 (I923), werit of error denied, 267 U. S. 575 (Ig25) ; State ex rel. Anderson v. Fousek, 9I Mont. 448, 8 P. (2d) 79I (I932); State $c x$ rel. Olson v. Langer, 256 N. W. 377 (N. D. 1934) ; State ex rel. Salisbury v. Vogel, 256 N. W. 404 (N. D. 1934).

52. People ex rel. Barnett v. Bartlett, I69 I1l. App. 304 (I9I2) ; State ex rel. Mitchell v. McDonald, I64 Miss. 405 , I45 So. 508 (I933).

53. See State v. Redman, I83 Ind. 332, 340, I09 N. E. 184, I87 (1915); State ex rel. O1son v. Langer, 256 N. W. 377, 385 (N. D. I934) (I935) 83 U. of PA. L. REv. 386, 387; (1935) 48 HARv. L. REv. 687; (I935) 49 HARv. L. REv. I57, I58.

54. See State v. Gooding, 22 Idaho I28, 132, I24 Pac. 791, 792 (Igr2); People ex rel. Barnett v. Bartlett, 169 I11. App. 304, 306 (I9I2). 
Besides the factual situations already mentioned, there are several which are more closely related to the criminal law, in which the extent of a criminal's punishment may be affected by a foreign conviction. In one case, $^{55}$ a statute provided that suspended sentences could be set aside upon conviction of the defendant of another felony. It was held that defendant's suspended sentence could be set aside because he had been convicted of a felony in another jurisdiction. In another case, ${ }^{56}$ defendant's sentence was commuted upon the condition that, if he should thereafter be "convicted of any felony," he should be deemed an escaped convict. Defendant was later convicted of a felony in another state. After distinguishing a case involving the effect of a foreign conviction upon a witness's competency, the court, by way of dictum, expressed its belief that the foreign conviction was included within the phrase "convicted of any felony", and Pound, J., said: "Good behavior, although determined to some extent by local standards, is not a matter of geography. . . ." 57 What these decisions actually did was to look to the spirit, rather than the letter, of the law, in order that the culprit should not escape his just punishment. The court's sympathy for the defendant is considerably mitigated in these cases by the fact that there is involved a second offense. It is submitted that the statutes here involved were more penal in nature than, for example, those excluding from the office of executor anyone convicted of crime. Yet in the latter situation, ${ }^{58}$ the same court permitted a man convicted in another jurisdiction to escape the disqualification prescribed in the statute, on the grounds that penal laws have no extraterritorial effect.

A somewhat similar problem arose as to the interpretation of the Baumes law, ${ }^{58 \mathrm{a}}$ which provided a heavier penalty for a convict previously convicted of a crime punishable by imprisonment in a state prison. Was this meant to embrace previous convictions elsewhere? Such a situation presented itself, but the court expressly reserved the question. ${ }^{59}$ In the meantime, the penal law had been amended, so that the problem has now become purely academic. Thus today there is no doubt that under the express provisions of so-called multiple conviction statutes, foreign convictions are given extraterritorial effect. ${ }^{60}$ Similarly, a statute granting indeterminate sentences to persons "never before convicted of a crime punishable by imprisonment in a state prison" has been held not to entitle to an indeterminate sentence one who was previously convicted in another state. ${ }^{61}$ The court relied upon a section of the same statute which directed all its provisions to be construed "according to the fair import of their terms to promote justice and effect the objects of the law."

An important question arises when the two jurisdictions involved are state and federal. It has been held in some instances that state and federal

55. Brown v. State, ro5 Tex. Cr. App. 586, 289 S. W. 682 (1926).

56. People ex rel. Atkins v. Jennings, 248 N. Y. 46 , 16I N. E. 326 (1928).

57. Id. at $52,16 \mathrm{I}$ N. E. at 328 .

58. See supra, p. 216.

582. N. Y. PENAL LAW \$§ I94I-I943.

59. People v. Guttersohn, 244 N. Y. 243, I55 N. E. II3 (I926) ; cf. People v. Caesar, I Park. Cr. 645 (N. Y. I855).

6o. People v. Wood, I45 Misc. 678, 26I N. Y. Supp. 892 (County Ct. Saratoga County 1932) ; State v. Malusky, 59 N. D. 50r, 230 N. W. 735 (I930). ISI2).

6I. People ex rel. Murray v. Becker, 78 Misc. 666, 138 N. Y. Supp. $77 x$ (Sup. Ct. 
courts are foreign to each other in the same sense that the courts of two states are foreign, because they derive their jurisdiction from different governments, and the fact that both courts enjoy the same territorial jurisdiction is immaterial. ${ }^{62}$ So distinct are the two sovereignties, that an act denounced as a crime by both is an offense against both, and may be punished by each. ${ }^{63}$ Logically, therefore, a conviction in the federal courts should be treated by the state courts as a foreign conviction, and the same attitude should be adopted by federal courts in respect to convictions in state courts. And in fact the particular rule governing foreign convictions is almost invariably applied to federal convictions by state courts. ${ }^{64}$ An extreme example is Ex parte Quarrier. ${ }^{65}$ In that case, the court admitted to the bar a man who had participated in rebellion against the United States, on the ground that this did not constitute an offense against the state.

On the other hand, an offense against federal law is an offense against the "supreme law of the land" 66 and a few state decisions have balked at treating a federal conviction as if it were rendered by a foreign court. ${ }^{67}$ In one of these, an attorney who had been convicted by a federal court was disbarred, but the court limited this rule to convictions by federal courts sitting in the same state. ${ }^{68}$ And in at least one constitution, federal convictions are placed upon the same basis as convictions in the courts of the state. ${ }^{69}$

As has been already observed, ${ }^{70}$ a foreign conviction does not disqualify a witness, and it follows that conviction in a federal court does not disqualify a witness in a state court. ${ }^{71}$ This is true although both state and federal statutes prohibit a convict from testifying," because "neither the State statute nor the Federal statute . . . could impose the punishment imposed by the other, nor can the courts of either take cognizance of or punish violations of the statutes of the other. . . . 73

It remains to examine the effect of a conviction in a state court upon the competency of a witness in federal tribunals. Despite the rule that the federal courts are governed by the rules of evidence of the state in which

62. Goldey v. Morning News, 156 U. S. 518 ( 1895 ) ; Brown v. United States, 233 Fed. 353 (C. C. A. 6th, I9I6). (I922).

63. Moore v. Illinois, I4 How. I3 (U. S. I852) ; United States v. Lanza, 260 U. S. 377

64. E. g., Barnes v. District Court, 178 Cal. 500, I73 Pac. IIoo (rgI8) ; In re Ker1, 32 Idaho 737, I88 Pac. 40 (I920); Leonard v. Leonard, I5I Mass. I5I, 23 N. E. 732 (I890); State ex rel. Anderson v. Fousek, 9I Mont. 448, \& P. (2d) 791 (I932); In re Canter's Estate, I46 Misc. I23, 26I N. Y. Supp. 872 (Surr. Ct. I933); Amaya v. State, 87 Tex. Cr. 160,220 S. W. 98 (1920).

65. $2 \mathrm{~W}$. Va. 569 (I866). Although there was no conviction involved, the case is an excellent illustration of the attitude of a state court toward violation of federal law.

66. U. S. Const. Art. VI, \$2.

67. See United States v. Barefield, 23 Fed. I36, I37 (E. D. Tex. I885) ; State ex rel. Sanford v. Riddle, 2r3 Ala. 430, 433, I05 So. 259, 262 (I925); State ex rel. Oison v. Langer, 256 N. W. 377,387 (N. D. I934).

68. State ex rel. Sanford v. Riddle, 213 Ala. 430, I05 So. 259 (I925).

69. Neb. Const. art. VI, §2.

7o. Supra, p. 2I4. II43.

7I. See I Bishop, Criminal LAw (9th ed. I923) §976; Note L. R. A. I9I7A II38,

72. Samuels v. Commonwealth, IIo Va. 901, 66 S. E. 222 (I909); Kain v. Angle, III Va. 415,69 S. E. 355 (1910). (Ig09).

3. Cardwell, J., in Samuels v. Commonwealth, IIo Va. 90r, 903, 66 S. E. 222, 223 
they are sitting, ${ }^{74}$ conviction in a state court does not generally disqualify a witness in federal courts, ${ }^{75}$ although clearly he would not be competent in the state courts. These decisions, no doubt, are attributable to "the tendency of modern thought towards the abolition of archaic rules which arbitrarily debarred certain classes from testifying," ${ }^{76}$ despite the interest of litigants in having the testimony of all acquainted with the facts, an interest which exists even though the witness's credibility may be impaired by anti-social conduct.

This tendency is so strong that although a federal statute renders a witness incompetent who has been convicted of crime, it has been held that even a conviction in federal courts will not disqualify a witness in federal courts. $^{77}$ This result was achieved by relying upon the removal of such disability by the law of the state in which the federal court was sitting, and reiteration of the rule that, as to procedure, federal courts follow the rules of the state in which they sit. Thus, through divers direct and indirect means, the federal courts have so limited the effect of a conviction, whether in a state or federal court, that one judge was led to remark: ". . . the common law rule [as to the incompetency of a convict to testify] does not obtain in federal courts. . . ."78

When the law of the forum differs from that of the state of conviction, serious difficulties may arise in the application of the foregoing rules. Of course, when it has been decided that a foreign conviction can have no extraterritorial effect by way of disabilities, the variation of the criminal law from jurisdiction to jurisdiction presents no difficulty; in fact, the desire to dodge the conflicts question has been given as a reason for so deciding. ${ }^{70}$ But this problem has considerably embarrassed courts in cases where, because of either statute or previous decision, foreign convictions may work a disability. For example, suppose a statute of the forum disqualifies anyone "convicted of felony, either within or without this state." If one is convicted of an act which is a felony in the state where the conviction is rendered, whether or not he is under a disability mentioned in the hypothetical statute may depend upon whether the same act, if committed within the forum, would have been, under the law of the forum, a felony, no crime whatever, or a misdemeanor. On the basis of these three possibilities, the cases and statutes may be roughly divided into three classifications.

The first group of decisions, which probably represents the majority, gives effect to the foreign conviction of felony, provided that the act committed also constitutes a felony in the forum..$^{80}$ But farther than this it re-

74. United States v. Reid, I2 How. 36I (U. S. 185I) ; 34 STAT. 6 I8 (Ig06), 28 U. S. C. A. $\$ 63$ I (I928); 6 HUGHES, FEDERAL PRACTICE (I93I) \& 3605.

75. Logan v. United States, I44 U. S. 263 (I892) ; Rosen v. United States, 245 U. S. 467 (I9I8) ; Pakas v. United States, 245 U. S. 467 (Igr8) ; Brown v. United States, 233 Fed. 353 (C. C. A. 6th, I9I6); 6 HUGHEs, FEDERAL PRACTICE (I93I) $\$ 3606 \mathrm{n}$. Contra:
United States v. Barefield, 23 Fed. I36 (E. D. Tex. I885).

76. I Bishop, Criminat Law (9th ed. rgz3) $\$ 976$.

77. Wise v. Williams, I62 Fed. r6I (C. C. S. D. N. Y. 1908); McCoy v. United States, 247 Fed. $86 \mathrm{r}$ (C. C. A. 5th, r918); Hagan v. United States, 9 F. (2d) 562 (C. C. A. 8th,

78. Lewis, J., in Hurwitz v. United States, 299 Fed. 449,453 (C. C. A. 8th, I924).
79. See supra, p. 214.

80. Chase v. Blodgett, Io N. H. 22 (I838) ; State v. Malusky, 59 N. D. 501,230 N. W. 735 (I930) ; Pitner v. State, 23 Tex. App. 366, 5 S. W. 2 Io (I887). 
fuses to go, and if the act is not a felony as defined by the laws of the forum, although it may be a felony in the state which rendered the conviction, it can have no effect. ${ }^{81}$ This method of treatment has been incorporated into a few statutes. ${ }^{82}$ It supplies an easily applied rule of thumb, and makes all disabilities depend solely upon local law. In applying this rule it has been held that, in order to give effect to the foreign conviction, there must be affirmative proof that the act upon which the conviction was based, if committed within the forum, would constitute a felony under the laws of the forum. ${ }^{83}$ In its operation, this rule has produced some slightly unpalatable results. For example, a New York court refused to give effect to a Michigan conviction of larceny and sentence of two to five years, on the ground that the act might only have constituted a misdemeanor in New York. ${ }^{84}$

The second group of decisions is well illustrated by State ex rel. Olson v. Langer. ${ }^{85}$ In that case, the North Dakota constitution excluded from public office anyone convicted of felony. The Governor was convicted in a federal court of conspiracy, which is a felony under federal law, but only a misdemeanor under the law of North Dakota. Quo warranto proceedings were then instituted against him and were successful. The opinion written by Judge Burke stated: ". . . whether an offense for which a conviction is had is a felony must be determined by the law of the jurisdiction where it is committed." 86 A number of decisions have handled the problem in an identical fashion. ${ }^{87}$ In disbarment proceedings, the convicted attorney is invariably held to be under a disability upon the bare showing that the act which he committed was a felony in the jurisdiction in which he committed it.88 Thus, the approach adopted by these cases also furnishes a convenient rule of thumb, but completely disregards the law of the forum. It has been doubted whether it would be adhered to if an extreme situation were presented. ${ }^{89}$

Between these two extremes is a small group of cases which adopts an intermediate view. They hold that a conviction of felony in a foreign jurisdiction imposes a disability if the same act is an offense punishable by the laws of the forum, whether a felony or a misdemeanor..$^{90}$ But they refuse to give effect to a foreign conviction of felony if the act committed consti-

S1. People ex rel. Atkins v. Jennings, 248 N. Y. 46, I6I N. E. 326 (1928); People v. Davis, I4I Misc. 897, 253 N. Y. Supp. 5 II (Ct. Gen. Sess. N. Y. Co. I93I); People v. Wood, I45 Misc. 678, 26I N. Y. Supp. 892 (Co. Ct. Saratoga Co. I932); Frantz v. Frantz, II Pa. Co. 467 (I892); Goldstein v. State, 75 Tex. Cr. App. 390, 17I S. W. 709 (IgI4).

82. E. g., N. Y. PENAL LAW (I909) § I 44 I.

83. People v. Voelker, 220 App. Div. 528, 221 N. Y. Supp. 760 (4th Dep't I927) ; People v. Knox, 223 App. Div. I23, 227 N. Y. Supp. 4I7 (4th Dep't I928); People v. Castellano, 228 App. Div. 670, 238 N. Y. Supp. 895 (2d Dep't 1929).

84. People ex rel. Atkins v. Jennings, 248 N. Y. 46, I6I N. E. 326 (1928).

85. 256 N. W. 377 (N. D. I934).

86. Id. at p. 389 .

87. State ex rel. Anderson v. Fousek, 9I Mont. 448, 8 P. (2d) 791 (I932); State ex rel. Salisbury v. Vogel, 256 N. W. 404 (N. D. I934); State ex rel. Beckman v. Bowman, 38 Ohio App. 237, r75 N. E. 891 (1930) ; Brown v. State, I05 Tex. Cr. App. 586, 289 S. W. 682 (I926) semble.

88. In re Ker1, 32 Idaho 737, I88 Pac. 40 (I920) ; In re Minner, I33 Kan. 789, 3 P. (2d) 473 (I93I) ; Matter of Ackerson, 2I8 App. Div. 288, 218 N. Y. Supp. 654 (Ist Dep't I926). 89. See (I935) 83 U. of PA. L. Rev. 386, 387; (I935) 29 ILI. I. REv. 945, 947.

90. State ex rel. Sanford v. Riddle, 213 Ala. 430, 105 So. 259 (I925); Matter of Comyns, I32 Wash. 391, 232 Pac. 269 (Ig25); see Ex parte Biggs, 52 Ore. 433, 435, 97 Pac. 713, 7I4 (1908). 
tutes no crime under the law of the forum. ${ }^{91}$ At least one statute ${ }^{92}$ has embodied this principle. It is interesting to note that had the Supreme Court of North Dakota utilized such a method of reasoning in the Langer case, the same result would have there been achieved. Under this view there is danger that convictions in the federal courts of crimes which are, by their very nature, exclusively crimes against the national government, ${ }^{93}$ may be considered as ineffectual to disqualify in a state court. ${ }^{94}$ But when such a situation arises, courts are alert to find that a crime under state law was actually committed, although perpetrated in such a manner or through such an agency that a violation of federal law was incidentally involved. ${ }^{95}$

Whenever a statute disqualifies for conviction of a crime "involving moral turpitude", the necessity for examining the difference between the laws of the forum and the state in which conviction occurs disappears. Under such a statute it is immaterial what differences, if any, exist. The courts decide whether the offense is one "involving moral turpitude", and if it is, the disability attaches. ${ }^{96}$ Of course, in determining this question, local standards are applied, although the act was commited elsewhere.

Usually, it is considered immaterial whether or not the law of the state where the conviction occurred imposes disabilities similar to those existing in the forum. ${ }^{97}$ That fact is treated as being foreign to the issue as to whether or not the foreign conviction shall be given extraterritorial effect, and apparently correctly so. But at least one case points out that the state of conviction imposed no disqualification upon a witness because of criminal conviction, and upon this ground decides that the foreign conviction was ineffectual to render a witness incompetent. ${ }^{98}$

\section{Conclusion}

It can readily be seen that the basic rule laid down by Chief Justice Marshall, ${ }^{99}$ that courts of one country will not execute the penal laws of another, is not helpful in determining the extraterritorial effect of criminal convictions in all cases. This results from the great confusion existing as to what constitutes a "penal law." 100 The only manner in which order can be

9I. People v. Guttersohn, 244 N. Y. 243, I55 N. E. II3 (I926) ; Ex parte Biggs, 52 Ore. 433, 97 Pac. 713 (Ig08); see (I935) 83 U. OF PA. L. REv. 386, 387.

92. Ontario Rev. Stat. I887, c. I48, § 34 .

93. Such as using the mails to defraud, interstate traffic in women for immoral purposes, etc.

94. People v. Guttersohn, 244 N. Y. 243, I55 N. E. II3 (1926).

95. State ex rel. Sanford v. Riddle, 213 Ala. 430, I05 So. 259 (1925); Matter of Comyns, I32 Wash. 39I, 232 Pac. 269 (I925).

96. Barnes v. District Court, I78 Cal. 500, I73 Pac. Iroo (I9r8) ; In re O'Connell, I84 Cal. 584, I94 Pac. Ioro (I920) ; White v. Andrew, 70 Colo. 50, I97 Pac. 564 (I92I) ; Matter of Hopkins, 54 Wash. 569, I03 Pac. 805 (I909) ; Matter of Finch, I56 Wash. 609, 287 Pac. 677 (I930).

97. See Harrison v. Moncravie, 264 Fed. 776,783 (C. C. A. 8th, I920), appeal dismissed, 255 U. S. 562 (Ig2I).

98. Langdon v. Evans, I4 Dist. Col. I (I883).

99. Supra, p. $2 \mathrm{I} 3$.

100. There is even confusion among the decisions of a particular jurisdiction, e. g., New York. Compare Sims v. Sims, 75 N. Y. 466 (I878) and In re Canter's Estate, I46 Misc. I23, 26r N. Y. Supp. 872 (Surr. Ct. 1933) with Matter of Lindheim, I95 App. Div. 827, 189 N. Y. Supp. 2 Ir (Ist Dep't Ig2r) and People ex rel. Atkins v. Jennings, 248 N. Y. 46 , I6I N. E. 326 (I928). 
produced out of the chaos is to classify the cases according to their facts, and then to determine under what circumstances courts will give effect to foreign convictions. A study of the decisions and statutes indicates that, although originally the provincial attitude was strictly adhered to, the recent trend apparently is to give effect to criminal convictions without regard to where the conviction was had.

There is also a tendency to give federal convictions the same weight as convictions obtained in the forum, while at the same time the courts do lip service to the theory that federal courts and state courts are foreign to one another.

As to how to treat differences in the law of the forum and the state of conviction, the objective is to reach a solution which will result in a minimum of injustice. ${ }^{101}$ The two major' groups of decisions are too extreme, one placing too strict, and the other too loose a construction upon disqualifying statutes. The "moral turpitude" treatment is applicable to only a particular type of statute. Moreover, "moral turpitude" is so vague a term, varying according to time and locality, that it is not very helpful and hampers uniformity. ${ }^{102}$ The most practical solution seems to be the intermediate view of disregarding the arbitrary ${ }^{103}$ distinction between felonies and misdemeanors. If effect is given to a foreign conviction of felony only when the crime is also punishable under the laws of the forum, whether as a felony or misdemeanor, a rule is laid down which is definite, and which takes into consideration both the law of the forum and the law of the state of conviction.

Finally, it can be seen that the problem of the extraterritorial effect of criminal convictions is largely a matter of statutory construction. Here, as in so many other fields, much confusion and uncertainty could be eliminated if statutes were more carefully drafted. It is to be hoped that in the future, legislatures will evidence a more intelligent appreciation of the difficulties which exist in this field. ${ }^{104}$

$$
\text { S. S. A., Jr. }
$$

\section{Redefinition of Mortgage Deficiency}

Much has been written recently regarding relief of the mortgage debtor. ${ }^{1}$ Most of this material has concerned itself with comparative analyses of various methods of reaching the desired result. In view of the fact that the legal problems arising from the application of each of these are distinct, this

IOI. See (1935) 29 Irc. L. REv. 945, 947.

102. See United States ex rel. Mylius v. Uhl, 203 Fed. I52, I54 (S. D. N. Y. I913); Drazen v. New Haven Taxicab Co., 95 Conn. 500, 507, III Atl. 861, 863 (I920); Ex parte Mason, 29 Ore. I8, 23, 43 Pac. 651, 652 (I896); Beck v. Stitzel, 21 Pa. 522, 524 (1853); Note (I929) 3 So. CaI. L. Rev. 46, 49; Note (I929) 43 HARV. L. Rev. II7, I2r; (I935) 83 U. OF PA. L. REV. 386,387 .

I03. See Ex parte Biggs, 52 Ore. 433, 435, 97 Pac. 7I3, 7I4 (Ig08) ; Lynch v. Commonwealth, $88 \mathrm{~Pa}$. I89, I92 (I878).

104. No attempt has been made in this study to examine the effect of either pardons or pending appeals.

I. Feller, Moratory Legislation: A Comparative Study (I933) $46 \mathrm{H}_{\mathrm{ARv}}$. L. Rev. IO6I; Note (1934) 82 U. of PA. L. REV. 26I; Note (I933) 42 YALE I. J. 960. For a thorough case discussion see Langever v. Miller, 76 S. W. (2d) ro25 (Tex. Sup. Ct. 1934). 
note will be confined to a consideration of that method which a fast-growing body of case law indicates may well be generally adopted in the futurejudicial and legislative redefinition of the amount of the deficiency remaining payable by the mortgagor after foreclosure and sale of the mortgaged premises.

What right has a creditor-mortgagee to any amount over and above the actual proceeds realized at foreclosure sale? Not so many years ago such a question would have been brushed aside as a fanciful attack upon the then unquestioned rule of law that foreclosure and sale does not exhaust the mortgagee's rights unless the proceeds entirely satisfy the debt. But the clash of conflicting interests of debtor and creditor in times of social crisis frequently necessitates an analytical re-examination of well-established legal doctrines. And so this question has been put recently, challenging the old upon its merits, suggesting that perhaps another rule might be economically more justifiable. ${ }^{2}$ Consequently a prefatory paragraph in explanation and justification of deficiency judgments is advisable.

At early common law, $O$ the owner of Blackacre as the price of obtaining a loan from $A$ was required by the latter to give not merely a bond but also a fee simple deed to Blackacre. From the moment of legal delivery of this deed the mortgagee $A$ was owner of the land and entitled to immediate possession. $^{3}$ Title was defeasible on due performance of the stipulated obligation but absolute on default. Where the value of Blackacre exceeded the indebtedness, loss of the power to redeem was a palpable injustice to the mortgagor and a contributing factor to the development of equity's jurisdiction and of the lien mortgage.

Under either title or lien theory, the mortgage device in reality is historically merely one method of providing security for the creditor's protection. It was in cases where the forced sale of the security, Blackacre, failed to realize the face of the debt, that the legal device of deficiency judgment was developed in order to safeguard the mortgagee. ${ }^{4}$ Equity's original solicitude for the oppressed mortgagor had been tempered by a growing respect for the rights of the creditor-mortgagee.

Modern courts attempting to find reasons for the rule have frequently paraphrased the rule itself by emphasizing the moral obligation of the mortgagor to pay what he owed.5 Seemingly this begs the question, since the problem is whether the mortgagor should owe anything after the mortgagee has seen fit to sell the security. However, there are more substantial bases for the rule. Such sale does not in fact indicate an intention to discharge the

2. "We are confronted with a new theory to the effect that the mortgagor has a legal right to completely settle a mortgage obligation by tendering to the mortgagee a deed to the property mortgaged." Security Benefit Ass'n v. Swartz, 40 P. (2d) 433, 435 (Kan. I935).

3. Cook v. Curtis, I25 Me. II4, I3I Atl. 204 (I925) ; Brown v. Cram, I N. H. I69 (I8I8). It is interesting to note that in Alabama even today this seems to be the rule. "The mortgagor, before or after default, except by agreement, does not possess even the right of possession as against the mortgagee." Mallory v. Agee, 226 Ala. 596, 600, I47 So. 88I, 883 (I932).

4. 3 Jones, Mortgages (8th ed. I928) $\$ 2205 ; 2$ Wirtsie, MortGage Foreclosure (4th ed. 1927) \$ 949 et seq. See Amory v. Fairbanks, 3 Mass. 562 (I793).

5. It has been suggested, however, that the motives of the mortgagor should be taken into account, and if he be found to be "speculating upon the return of prosperity" no relief should be granted. Fifth Ave. Bank of N. Y. v. Compson, II3 N. J. Eq. I52, I66 At1. 867 (I933). Such an inquiry into the mental state of the parties would not seem practicable. 
debtor. Fundamentally, security is designed to increase and not to limit the means of the creditor to realize the principal which it was given to secure. In the face of these two grounds there seem to be no considerations of social policy warranting a conclusive presumption that the parties had a contrary intention. If there were such a presumption, creditors could adequately protect themselves only by requiring so much security that the debtors would in all probability be unable to produce it, thus "freezing" credit extension.

If the intent of the parties is, then, to be given effect, the mortgagee in many cases may be regarded as justly entitled to recover more than has been realized at foreclosure sale. The question is-how much more? The classic method of determining this amount has been the automatic designation as deficiency of the balance of the mortgage debt remaining unpaid after deduction of the proceeds of foreclosure (less costs, expenses, taxes and other liens) from the mortgage debt. ${ }^{6}$ A factor undoubtedly looming large in the original adoption of this means of measurement was its simplicity of arithmetical computation. In periods of what might be called ordinary economic stress, its application probably effected an equitable result in the majority of cases, the mortgagee being assured of a return approximating the true value of the foreclosed premises and the mortgagor a proportionately large scaling down of the mortgage debt. Frequently this more or less normal demand for the land on the part of potential purchasers was within the contemplation of the parties upon execution of the mortgage.

Absence of criticism of the classic method in the past, however, has not been due to its intrinsic virtues. Fundamentally it restates the conviction that property sold at judicial sale is worth only what it brings-a wholly misleading generality which does not distinguish between worth in the sense of value and worth in the sense of price. Nothing has emphasized the fact of the existence of this distinction more effectively than the tremendous list of properties sold at sheriff's sale in any large city for ridiculously small sums. The failure of the least realistic modern courts either to recognize this fact, ${ }^{7}$ or recognizing it, to accord it legal significance, ${ }^{8}$ cannot conceal the inadequacy of the classic judicial sales device to safeguard the mortgagor both today and in an appreciable minority of cases in the past. $\mathrm{He}$ loses the land which is sold for next to nothing, and still remains personally obligated to the mortgagee for practically the face of the bond. ${ }^{9}$ And where the mortgagee is in fact the purchaser, as is generally the case, either in his own name or through another, he profits to the extent that the value of the property exceeds the price actually brought. Under such circumstances, foreclosure is not in actuality a sale of security, but a speculative investment on the part of the

6. 3 JoNes, op. cit. supra note 4 , at § 2219; 2 WIITSIE, op. cit. supra note 4 , §949 et seq. 7. In a typical case the court indicated that the fact that three sales had elicited no higher offer than $\$ 27,600$ was substantial evidence against an affidavit that the land was really worth $\$ 100,000$. Merchants' Nat. Bank of Point Pleasant v. Ralphsnyder, II3 W. Va. 480, 486, I69 S. E. 89, gr (1933).

8. "Mere inadequacy of consideration, however gross, unaccompanied by inequitable conduct, in connection with a judicial sale, is, of itself, insufficient to justify the court in setting the sale aside and refusing confirmation thereof." Southern Grocery Co. v. Merchants Co., 186 Ark. 615, 617, 54 S. W. (2d) 980, 981 (1932).

9. New Jersey courts have been particularly prominent in pointing out this fact. Baader v. Mascellino, II3 N. J. Eq. I89, I66 At1. 466 (1933); Federal Title \& Mortgage Guaranty Co. v. Lowenstein, II3 N. J. Eq. 200, I66 At1. 538 (I933). See also Langever v. Miller, 76 S. W. (2d) 1025 (Tex. Sup. Ct. 1934). 
mortgagee-purchaser. It is little wonder, then, that recently courts and legislatures have recognized these defects arising from the rigidity of the classic method, and have redefined deficiency to secure a flexibility achieving a nicer balance of the equities between the parties, a balance that is not disturbed by changing economic conditions.

\section{Judicial Redefinition in the Absence of Statute}

A few courts heretofore adhering to the classic method have found a way recently to achieve a socially satisfactory result without benefit of statute. Where the price brought is grossly inadequate, the decree of sale is not confirmed unless the mortgagee consents to an equitable means of measuring the deficiency. ${ }^{10}$

Since in the past refusal to confirm has been the exception rather than the rule, some courts may consider it an embarrassing problem to square this new method with lack of precedent. However there is general agreement that courts have always had the power to refuse confirmation. ${ }^{11}$ The past practice simply indicates absence of sufficiently compelling circumstances. Despite the majority view that the purchaser has no rights in the land until confirmation, ${ }^{12}$ a few comparatively recent cases indicate that even before confirmation the purchaser is to be regarded as equitable owner. ${ }^{13}$ Possibly courts holding the latter view will have more hesitancy in denying confirmation than those purporting to interfere with no rights of the purchaser.

One difficulty in the problem is the fact that much more has been said than has been actually held. Thus, inadequacy of price, in itself, has been repeatedly declared insufficient to bar confirmation. ${ }^{14}$ Some additional factor,

10. This is accomplished by any one of a variety of procedures. See infra notes 30-33 inclusive.

II. "Until confirmation by the court the sale is incomplete. Confirmation is not a mere formality, but is a judicial act although it is uncontested. The acceptance of the bid confers no title on the puchaser, and not even any absolute right to have the purchase completed. $\mathrm{He}$ is nothing more than a preferred bidder, or proposer for the purchase, subject to the sanction of the court afterwards." 3 Jones, Mortaages (8th ed. I928) \$2I03.

12. The purchaser has no vested right till confirmation. Layton v. Rhode Island Hospital Trust Co., 205 Fed. 276 (C. C. A. 8th, Ark. I9I3). "Both public and private salesunder decrees of court are subject to the approval of the court, and, until ratified, any sale is only an offer to purchase." Whitely v. Whitely, II7 Md. 538, 544, 84 Atl. 68, 70 (rgr2). Upon confirmation, title is treated as having been in the purchaser from the day of sale. Dixon v. Osborne, 204 N. C. 480 , I68 S. E. 683 (I933); Watkins v. French, I49 Okla. 205, 299 Pac. 900 (I93I).

I3. "While some of the Kentucky cases following Hues v. Swope seem to cast doubt upon the rule there announced, and while it has been indicated, as in Manhattan Insurance Co. v. Stein and Zang, 5 Bush. (68 Ky.) 652, that it is the confirmation of the sale that determines the effective transfer of ownership, it is, we think, clear, from an examination of the later Kentucky cases, that the principle is now established that where at the time a sale is made no valid ground for setting it aside exists, the accepted bidder is entitled to his purchase, and is the equitable owner." Fidelity-Phoenix Fire Ins. Co. v. Hayward, 7I F. (2d) 834 (C. C. A. 6th, I934). Whether or not one speaks in terms of "offer" and "ratification", it seems clear that the majority of older cases conclude the purchaser is not the owner for all purposes until confirmation.

I4. ". . . - mere inadequacy of price is not per se sufficient to authorize a rejection of sale by a court, unless it is so grossly sacrificial as to shock the conscience or create a presumption of fraud." Louisville Title Co. v. Ramsey, 79 S. W. (2d)! 693, 694 (Ky. I935). In many states judicial sales made without irregularity or fraud, and not affected by accident or mistake, will not be'set aside for mere inadequacy of price. Hecht v. Hoogmoed, Iro N. J. Eq. I63, I62 Atl. 873 (I932) ; Adams v. Spillyards, I87 Ark. 64I, 6r S. W. (2d) 686 (I933). 
according to the rule, must be present. ${ }^{15}$ The reports are replete with numerous holdings and still more numerous dicta that laches may prevent confirmation, as may fraud, misrepresentation, surprise, or mistake. ${ }^{16}$ Such statements, of necessity, are meaningless when dissociated from the facts of the individual case impelling the court to find sufficient legal basis for refusing confirmation.

The basic aspects of the problem are well illustrated in Suring State Bank v. Giese. ${ }^{17}$ Here the court declared that a price of $\$ 600$ on a $\$ 2000$ property, when coupled with the presence of a financial emergency, justified the trial judge in requiring the mortgagee to credit the debtor with the reasonable value of the property, and in ordering a resale in the event of failure to do so. It is worthy of note that the $\$ 2000$ valuation did not represent the then market value of the premises. ${ }^{18}$ Nor did it in actuality represent, as one commentator suggests, ${ }^{19}$ an estimate of potential market value. It is true that the opinion did mention this factor. But the same court in the later case of Kremer $v$. Rule ${ }^{20}$ makes it clear that the valuation fundamentally reflected the intrinsic worth of the land at the time of foreclosure sale, rather than past or probable future price. ${ }^{21}$ The result is emphasized by the fact that the trial judge was reversed for considering the Suring case as sustaining the standard of potential market value. The importance of the holding lies in the reason given for refusing confirmation. Formerly the factor generally insisted upon in addition to inadequacy of price was at least nominally some element existing as between the parties at the time of entering into the transaction giving one an undue advantage over the other, or causing both to labor under the same mistake of fact. ${ }^{22}$ It is true, of course, that courts displayed considerable ingenuity in discovering the presence of such an additional factor where the price was in fact grossly inadequate. Nevertheless, there has been an insistence upon its nominal presence, even though gross inadequacy in itself has been considered some evidence of fraud, surprise or mistake. ${ }^{23}$ To these the court in Suring State Bank v. Giese adds "state of

I5. Holt v. Holt, 59 S. W. (2d) 324 (Tex. Civ. App. 1933) ; Speers Sand \& Clay Works v. American Trust Co., 52 F. (2d) 83 I (C. C. A. 4th, I93I); Clegg v. Christensen, 346 IIl. 3I4, I78 N. E. 925 (I932).

I6. In re Pneumatic Tube Steam Splicer Co., 6o F. (2d) 524, 527 (D. Md. I932); Hecht v. Hoogmoed, II0 N. J. Eq. I63, 162 Atl. 873 (1932) ; Royal Highlanders v. Louthan, I23 Neb. 469,243 N. W. 267 (I932). But see the cases cited infra note 29.

I7. 2 I0 Wis. 489,246 N. W. 556 (I933), (I933) 8I U. OF PA. L. REv. 883; (I933) 42

Yale L. J. 96I ; (I933) 27 IrL. L. REv. 950; (1933) 33 CoL. L. Rev. 744.

I8. Id. at $49 \mathrm{r}, 246 \mathrm{~N}$. W. at 557 .

I9. See (I933) 27 Irt. L. REv. 950.

20. 216 Wis. 331,257 N. W. 166 (I934).

2r. Id. at $338,339,257 \mathrm{~N}$. W. at I69. ". . . the [lower] court wasi evidently of the opinion . . . that it could consider the market value of the premises which existed at some remote time under conditions deemed by the court to be normal. There is nothing in the Suring Case to justify that view .. . [the court] should not consider 'market value' as that expression is ordinarily used and understood, much less the value that the premises may have had at some remote time or may have in the future. . . . It should direct its attention to the matter of determining the real value [italics added] of the premises as of the time of the foreclosure sale."

22. Holt v. Holt, 59 S. W. (2d) 324 (Tex. Civ. App. I933) ; Clegg v. Christensen, 346 I11. 3I4, I78 N. E. 925 (I932).

23. In re Yost \& Cook, 70 F. (2d) 6I4 (C. C. A. 6th, I934) ; Schroeder v. Annapolis \& Chesapeake Bay Power Co., 2 F. Supp. 394 (D. Md. 1933) ; Metropolitan Life Ins. Co. v. Heany, 122 Neb. 747, 749, 24 I N. W. 525, 526 (I932). Cf. Lamb v. Kelley, 97 W. Va. 409, I25 S. E. 102 (I924). Obviously the "presumption" of fraud arising from "gross" inade- 
the times", of which it takes judicial notice, as a ground for refusal to confirm. The parties had dealt fairly with each other upon execution of the mortgage, and the realities of the situation force the recognition that refusal of such confirmation was actually due solely to what the court considered inadequacy of price resulting from a cause entirely extraneous to the specific transaction. ${ }^{24}$

What is the meaning of inadequacy of price in such a situation? Obviously, price can be inadequate only in relation to something else. As to what this other factor is, three answers have been given by various courts: (I) market value, (2) fair market value, (3) true, intrinsic, fair or reasonable value.

Despite statements to the contrary, there would seem to be no satisfactory distinction between price and market value. They are apparently one and the same thing, the amount the property will bring at public sale. Fair market value is purely a fiction and like all fictions should be a solution of last resort. In Market Street National Bank v. Huff, ${ }^{25}$ the Pennsylvania Supreme Court declared "When the Act speaks of 'fair value at the time of sale' it means what it says, namely, fair market value at the time of the sale, as fixed by men competent and qualified to express an opinion, not a surmise based on a future which no man can possibly forecast, and upon factors imagined and not now existing. There can be no other fair value except fair market value. Any other would not be fair, but speculative." 26 In view of the fact that the price brought at public sale was approximately two-thirds of what the court declared to be the "fair market value", it is difficult to conceive of a more speculative test than that here adopted. Perhaps the court feels that the sale is a forced one and that the inability of the vendor to negotiate at length with prospective purchasers has prevented his obtaining a maximum return. On the other hand, possible vendees at judicial sale are aware that the property is definitely going to be sold to the highest bidder, and they must make the most of their opportunity. Furthermore, in the theory of the law, the market value of property should be determined by the demand on the part of buyers and not the desires of the seller. At least this is so where there is no real market for the property. Though this alleged test of "fair market value" is perhaps a consciously loose definition in order to permit proper results, one cannot be blind to the fact that it is value in

quacy of price is not a presumption of fact but a rule of law to the effect that "gross" inadequacy of price will justify refusal to confirm.

24. An analogy exists between this situation and that where the vendee of a contract for the sale of land seeks specific performance in equity on the ground of insolvency of the vendor. There, courts frequently treat insolvency only as a makeweight and give specific performance because of a purported combination of insolvency with other grounds for equitable relief, when in fact such other grounds do not exist. Livesley v. Johnston, 45 Ore. 30,52 , 76 Pac. 946, 95I (1904). See Note (1934) 82 U. OF PA. L. Rev. 5 I5.

25. $319 \mathrm{~Pa}$. 286, I79 Atl. 582 (1935). This case is interesting because the Pennsylvania Deficiency Judgment Act of January 17, I934, P. L. 243 [PA. Stat. ANn. (Purdon Supp. 1934) tit. 2I, \& 806], which expired without a direct test of its constitutionality in the Pennsylvania Supreme Court, spoke of "fair value at the time of sale". The Act of 1935 restates this. Whether the interpretation adopted by the court in the instant case will be important in determining the constitutionality of the act remains to be seen. A lower court has already held the I935 act to be constitutional on the ground that were it not for the act there would be an "unjust enrichment of mortgagees at the expense of helpless mortgagors".

Phila. Leg. Intelligencer, Oct. 3I, 1935, at I.

26. Italics added. 
vacuo. The court is talking of market value when there is no market and adding an adjective to nullify the noun. Particularly does this seem to be true where the judge, unwilling to trust his own judgment or that of appraisers, leaves determination of the amount to a jury. ${ }^{27}$

The third test, favored by the majority of courts which have broken with the past, has been variously termed "fair", "real", "true" or "reasonable" value. The difference is one of nomenclature and not of substance. There has been as yet no conscious formulation of standards by which to measure this value, which would seem to rest upon the concept of an intrinsic worth, or use-value. To the objection that this is somewhat indefinite, at least one reply may be made. Perhaps in time such standards will evolve as they have done over a period of years in connection with the determination of the rates to be charged by carriers, such rates being based upon a "fair evaluation" of the carrier's property. ${ }^{28}$ The problem is not a simple one, and no graver error could be made than to attempt to achieve a mathematical formula to meet the creditor's cry for certainty. The important fact to remember is that fair value, however it may be measured, is not a fiction. It is indisputable that properties are worth more than the price they bring today, and a reasonable approximation of this difference is the most that should be expected.

The objection to inadequacy of price, in its true meaning, as a ground sufficent in itself to justify refusal to confirm rests fundamentally upon (I) unwillingness to determine minor inadequacies through detailed investigation by already overcrowded tribunals, and (2) the feeling that the parties have made their bargain and must abide by it. Whatever the basis, the fact that this rule of words and not of application has crystallized into law cannot be ignored. Courts that have refused to follow logic or to recognize the rule for what it is have nevertheless found at least one way of reaching what seems a desirable result. Thus, some courts have devised an artificial distinction which may point the way out while preserving intact the integrity of the classic formula-gross inadequacy of price will justify refusal to confirm whereas mere inadequacy of price will not. ${ }^{29}$ The vituperative epithet may

27. $\$ 4$ of the Pennsylvania Act of 1935 provides, "Any party in interest may, prior to the time of the hearing, demand in writing a jury trial on any material issue or issues of fact raised by the pleadings, whereupon the said issue or issues shall be determined by $a$ jury trial as in other cases."

28. In Farmer's and Mechanic's Savings Bank of City of Lockport v. Eagle Building Co., I53 Misc. 554, 276 N. Y. Supp. 246 (Sup. Ct. 1934), the court sustains the contention that in arriving at market value there should be taken into consideration replacement costs, usable floor area, condition of the building, location of the site, adaptability for various uses, fairness of assessed value, and the trend of the renting market.

It is significant that New York courts define "fair market value" as the price a willing purchaser would pay and for which a willing owner would sell. Under this definition, there is no escape from the conclusion that in the overwhelming majority of recent foreclosure sales there could be no such standard as "fair market value" simply because there were no willing buyers.

29. That such a distinction is not meaningful is well illustrated by the language of many cases. See supra note 8 . A clear holding that gross inadequacy of price is in itself sufficient is to be found in Lamb v. Kelley, 97 W. Va. 409, I25 S. E. I02 (I924). "In the earlier cases it was held that mere inadequacy of price was not a sufficient ground, but that such price coupled with an irregularity in the conduct of the sale would be sufficient. In later cases it was held that gross inadequacy of price is a sufficient reason to justify the setting aside of a sheriff's sale." In re Downham Co., I65 Atl. I52 (Del. Super. I932) (sale for $\$ \$ 50$ of canning factory costing $\$ 25,000$ and worth between $\$ 2000$ and $\$ 5000$ set aside 
explain away considerable case law of the past, and courts following the classic method have frequently found this a convenient aid to solution of their difficulties.

Refusal of confirmation, once determined upon, has been accomplished by a variety of procedures. Most direct has been outright refusal to confirm coupled with an absolute order of resale. Such a policy disregards the possibility that the mortgagee will consent to the imposition of equitable conditions, in which event there would be no need of holding another futile sale.

Another practice is the fixing of an upset or minimum price below which there will not be confirmation. It has met with a host of objections as applied to this situation in the law. ${ }^{30}$ It has been asserted that this contravenes statutes permitting deficiency judgments and amounts to the infliction of a penalty upon the mortgagee. ${ }^{31}$ The practice has, however, one great advantage in the situation where the plaintiff-mortgagee allows the property to pass into the hands of a third person at judicial sale in reliance upon obtaining a deficiency judgment for the balance of the debt. If he should not be able because of local law to obtain the arithmetical balance due according to the classic method of deficiency determination, the question of deprivation of property without due process of law might conceivably be raised. Such a contention could not be maintained successfully if the mortgagee were to be advised in advance of the sale as to the minimum price necessary to insure confirmation. He would then be able to protect himself up to the fair value of the premises as determined by the court, by bidding that amount and recovering a deficiency judgment for the remainder. Though the argument has been made that the theoretical reasons behind adoption of the upset price in corporate foreclosures and reorganizations are not present in the situation under discussion, ${ }^{32}$ it seems difficult to justify the casting aside of a practically-advantageous legal device simply because its application has hitherto been confined to a totally different legal problem.

The most common practice by far has been to allow the mortgagee the option of crediting the debtor with the reasonable value of the property rather than the price actually brought, resale being ordered on his refusal to do so. Where the price brought exceeds the value, as occasionally happens, the mortgagor is, of course, in no need of relief.

It should be observed that the adoption of any one of these procedures creates no conclusive certainty that the deficiency will be determined equitably. If the upset price is not bid, or the mortgagee rejects the option, the only alternative is to order the premises sold again. ${ }^{33}$ An endless succession of

since price brought was about half its value. On resale there was no bid. Finally the factory was sold to satisfy the claim of another creditor for \$̧80o); West Ridgelawn Cemetery v. Jacobs, I08 N. J. Eq. 513, I55 Atl. 673 (1931).

30. Michigan Trust Co. v. Cody, 264 Mich. 258, 265, 249 N. W. 844, 846 (I933); cf. United B. \& L. v. Newman, II3 N. J. Eq. 244, I66 Atl. 537 (I933).

3I. Michigan Trust Co. v. Cody, 264 Mich. 258,249 N. W. 844 (I933).

32. The upset price device is employed in corporate foreclosures to protect the mortgagees where the value of the property involved greatly restricts the number of possible purchasers. See Weiner, Conflicting Functions of the Upset Price in Corporate Reorganization ( 1927) 27 CoL. L. Rev. I32, 136. For a criticism of the device as applied to ordinary mortgage foreclosures, see Note (r933) 42 YAIE L. J. $960,962$.

33. See (I933) 27 ILL. L. REv. 950, and cases therein cited. 
resales is by no means an appealing prospect. But as a practical matter, foreclosing creditors in such situations do accept the alternative. Rejection would carry in its wake delay and expense, two considerations anxious creditors cannot ignore.

The question has been raised as to whether what has been said applies to setting aside of sales after confirmation and injunctive relief against the holding of a foreclosure sale. It would seem that confirmation places on the one seeking to have the decree set aside a burden heavier than would have been his in opposing confirmation beforehand. That denial of a deficiency judgment after confirmation is not within the rule of Suring State Bank v. Giese has been determined by the Wisconsin court in Kremer v. Rule. ${ }^{34}$ There it was held that upon confirmation the legal consequences prescribed by statute follow-among them rendering of judgment for the deficiency. Other courts, however, have extended the equitable principles above set forth to situations involving modification or setting aside of decrees already confirmed. ${ }^{35}$ Examination of the cases where injunctive relief against sale is sought discloses a noticeable hesitancy to declare what would, in effect, be a judicial moratorium. While such relief involves problems other than those of redefinition of deficiency, the attitude of the individual court toward refusal of confirmation undoubtedly has a very important effect on that court's views concerning restraint of sale or modification of a decree already confirmed. Thus, a jurisdiction which conditions confirmation on the mortgagee's doing equity might well consider prayers for restraint of sale as premature and petitions for setting aside completed sales as belated.

It should be emphasized that the imposition of equitable conditions on the mortgagee's right to foreclose has by no means as yet become a general practice. The significance of what has been done lies in the strong probability that jurisdictions that have changed their position will adhere to the newer view permanently, and not merely for the duration of the emergency which has provided the opportunity to prove its merits. It reflects the dual bases of equity-a higher morality and a recognition that circumstances alter cases. From a realistic standpoint more than procedural initiative is involved. Whereas moratory relief merely suspends the right to foreclose, judicial redefinition of deficiency directly affects the right itself. Those courts and writers declaring that the modus operandi of determining deficiency has merely been modified, ignore the actual fact of substantive redefinition of deficiency, without benefit of statute, accomplished through the application of principles inherent in the origin and being of equity.

\section{Legislative Redefinition of Deficiency}

Many legislatures have attempted to redefine deficiency. Frequently, it was impossible to give the proposed bills careful consideration because of other business or the necessity of immediate passage. In certain jurisdic-

34. 216 Wis. 331, 257 N. W. I66 (I934), cited supra note 21.

35. Washington v. Young, 224 Ala. 232, I39 So. 92 (I93ī) ; Barnes v. Freed, 342 Ill. 73, I73 N. E. 795 (I930). One allowing a report of sale to be confirmed, where objections later raised were then known, without exception or complaint, is not entitled to have the exceptions to sale sustained, and an order sustaining them should be reversed. Fidelity \& Columbia Trust Co. v. White Construction Co., $80 \mathrm{~S}$. W. (2d) 550, 55I (Ky. 1935). 
tions the statutes have been merely declaratory of the judicial redefinition, already an accomplished fact therein. ${ }^{36}$ In others, the courts of which had continued to adhere to the classic means of measurement, the expressed will of the legislature came as a fundamental change. All these statutes contain at least some elements of indirect compulsory imposition of equitable conditions on the foreclosing mortgagee. This is equally true whether the statutes are intended to be effective for the duration of the emergency only or embody a permanent policy. Regardless of the type of legislation involved, the problem of constitutionality is certain to be eventually brought forward by the contention that the obligation of contracts is impaired. This is a difficulty not faced in judicial redefinition since the decisions of a court, though they may be erroneous and subject to reversal on appeal, are certainly not unconstitutional. ${ }^{37}$

It has been held repeatedly that the "obligation of contracts" clause of the Federal Constitution is not violated where a statute affects only legally binding agreements to be entered into after its enactment. ${ }^{38}$ While such a result emphasizes the desirability of passage of laws with an eye to the future, it is unfortunately true that the great majority of legislators think only in terms of the present and of relieving distress the roots of which lie in the past. Consequently legislation of the types outlined above has been almost wholly intended to affect pre-existing obligations and has thus been directed toward achieving a result the prevention of which was the basic reason for the insertion of the "impairment of obligations" clause in our Constitution. ${ }^{39}$ So marked has been this tendency that occasionally severability of construction clauses have been omitted, and the court has felt itself obliged to declare the entire act unconstitutional, both as to future and preexisting obligations. ${ }^{40}$

Where statutes have recited an emergency as their basis, courts have been willing in some instances to stretch precedent and uphold the acts. Blaisdell v. Home Building and Loan Association ${ }^{41}$ has been frequently cited as supporting this position. The problem therein presented, however, was quite different from that here under discussion. The statute in that case provided for temporary suspension of the obligation while enactments redefining deficiency involve destruction of all or a portion of the right itself. Justification of these statutes has been found in power created by the emergency, or in a reasonable exercise of the police power. Fundamentally, however, analysis of the decisions discloses that such courts regard economic

36. Kan. Laws I933, c. 218. But Spec. Sess. Laws 1934, c. 3, \$2, provides that "prior to March I, I935, no deficiency judgment shall be enforced until the period of redemption as allowed by existing law . . . has expired." By the Act of 1935, c. 226, $\$ 2$, this provision is extended to January 15,1937 , in exactly the same language.

37. Central Land Co. v. Laidley, I59 U. S. I03 (I895).

38. Lehigh Water Co. v. Easton, I2I U. S. 388 (I887). See Von Hoffman v. City of Quincy, 4 Wall. 535 (1866).

39. The Federalist No. $44 ; 3$ Farrand, Records of the Federal Convention (I9II) 2I4; 2 Farrand, $i d$. 439. See also the opinion of Chief Justice Marshall, dissenting, in Ogden v. Saunders, I2 Wheat. 213, 355 (I827).

40. See in this connection the majority and dissenting opinions in Adams v. Spillyards, I87 Ark. 64I, 6r S. W. (2d) 686 (I933).

4I. 290 U. S. 398 (I934). The problem of whether deficiency judgment statutes are an exercise of the police power would seem to rest upon the individual court's determination as to whether they are intended to directly affect a particular group only (mortgagors) or the general public. 
conditions rather than precedent as controlling. Their emphasis is on "the times" rather than on "the law".

A typical statutory requirement is that the deficiency should be determined by subtracting the fair value of the land, rather than the price actually obtained, from the obligation. Varying with the jurisdiction, this "fair value" is to be determined by appraisers, by the court, or by a jury. Regardless of the procedure in ascertaining the amount of the deficiency every judge, when the issue of constitutionality is raised, faces this problem: property mortgaged for $\$ 1000$ brings $\$ 50$ at foreclosure sale. If a modern statute were in force, the mortgagor would owe nothing if the fair value of the premises was $\$$ Iooo. Before passage of the statute, in the absence of judicial redefinition, the deficiency judgment would have been for $\$ 950$. Can a court which feels, as does the Maryland Court of Appeals, ${ }^{42}$ that judicial redefinition is an unwarranted departure from law, justifiably conclude that such a statute is constitutional?

Where a mortgage is executed in a jurisdiction adhering to the classic view, subsequent enactment of a modern statute deprives the mortgagee of the deficiency judgment which would have been his under the law existing at the time of the mortgage execution. And under the legal rule that parties are presumed to contract with reference to the existing law, ${ }^{43}$ the mortgagee may successfully assert this right to a deficiency as a term of the mortgage, implied-in-law. In jurisdictions that had adopted judicial redefinition before the effective date of the statute, a different problem arises. In the event that the mortgagee is himself the purchaser he has nothing of which to complain since in the hypothetical situation put there would have been no deficiency even before enactment. However, where the purchaser is a stranger, courts in these jurisdictions would before passage of the statute have given the mortgagee a deficiency judgment. This distinction is justifiable since the mortgagee, no longer having the land, is denied the benefit of the excess of its intrinsic worth over the price obtained. The acts generally make no distinction as regards the identity of the purchaser, and where this is so the mortgagee sustains a definite loss. The argument might be made that he has nothing of which to complain, not having chosen to protect himself by buying in the property. This concept of a legal "duty" owed only to himself is highly unsatisfactory, embodying an almost penal element. It does not conceal the lessening in fact of the value of the creditor's right. This result is avoided by legislative enactments, such as the North Carolina statute, ${ }^{44}$, providing that the fair value of the property rather than the price brought should be deducted from the obligation only in the event that the mortgagee was himself, or through another, the purchaser at the foreclosure sale. Despite frequent statements that the identity of the purchaser should involve no difference in legal consequences, such a distinction seems eminently just.45

42. Kenly v. Huntington B. \& L. Ass'n, I66 Md. I82, I70 Atl. 526 (I934). The force of the court's holding is somewhat weakened by the admission that there was probably no gross inadequacy involved here since almost $\$ 4000$ was due in ground rents.

43. Adams v. Spillyards, I87 Ark. 64I, 6r S. W. (2d) 686; McCracken v. Hayward, 2 How. 608 (U. S. 1844).

44. N. C. CoDE ANN. (I935) §2593 (b).

45. For this reason among others, the original New Jersey statute [N. J. LAws I933, c. 82$, N. J. STAT. ANN. $\$ \$ 134-48,134-49]$ was held unconstitutional in Vanderbilt v. Brunton 
In the unusual situation where the mortgagor buys in the premises at a nominal figure, application of modern statutes making no distinction as to the identity of the purchaser results in a reduction of the debt manifestly contrary to constitutional provision. It is extremely unfortunate that the failure to make such a distinction obliges courts to declare such enactments unconstitutional in their entirety.

Attempted legal justification of these enactments has been based in large part upon the contention that they merely provide a modus operandi of measuring deficiency, affecting only the remedy afforded and not the substantive rights of the parties. ${ }^{46}$ The validity of this distinction has been generally recognized in constitutional law; however, it should be borne in mind that frequently modification of the remedy may amount to virtual deprivation of the right. In some jurisdictions the mortgagor may still maintain an action at law on the bond although equity will grant no deficiency judgment. Where this is the local law, deprivation of the remedy in equity would not seem to violate constitutional provisions, the right being accompanied by a remedy to enforce it which is equally as adequate as that taken away.

A practical test for determining whether there has been an "impairment of obligation" is the ease of assignability of the mortgage. Before passage of the modern statutes, transfer of the right would have netted the mortgagee a fair percentage of the face value. After enactment, the right is dissociated from all the benefits which had given it worth.

Where the legislation embodies a permanent policy its unconstitutionality seems even more clear. The doubtful doctrine that an emergency creates additional constitutional power cannot be enlisted to support a statute not purporting to be an emergency measure. Occasionally a statute will set out that it is merely declaratory of the already existing law, and that the courts accordingly had always enjoyed the jurisdiction to effect redefinition. ${ }^{47}$ This legislative opinion of the prior state of the law, while interesting, is of course not binding on the courts in the event that the statute is declared unconstitutional. The majority of courts wherein the constitutionality of statutes redefining deficiency has been tested have felt themselves obliged to declare them violative of the "obligation of contract" clause.48 A few have managed to salvage a provision that the act should apply to legally binding agreements executed after its enactment because of the presence of the ordinary sever-

Piano Co., III N. J. L. 596, I69 Atl. I77 (1933). For the same reason the new Act [N. J. LAwS 1935, c. 88, N. J. STAT. ANN. I935, \$\$ I34-49 (I) to I34-49 (3)] was held unconstitutional in Sayre v. Duffy, I79 Atl. 459 (N. J. Sup. I935).

46. It seems clear that the principal purpose of such statutes has been to affect the obligation of the mortgage debtor, perhaps directly by attempting to deprive the courts of jurisdiction to grant deficiency judgments or only a trifle less directly by adopting the "fair value" rule. See Adams v. Spillyards, 187 Ark. 64I, 6I S. W. (2d) 686 (I933); Langever v. Miller, 76 S. W. (2d) I025 (Tex. Sup. Ct. 1934).

47. Kan. Laws I933, c. 2I8. See sipra. note 36 .

48. In New Jersey see Vanderbilt v. Brunton Piano Co., III N. J. L. 596, I69 At1. I77 (I933), and Sayre v. Duffy, I79 Atl. 459 (N. J. Sup. I935). In Arkansas see Adams v. Spillyards, I87 Ark. 64I, 6I S. W. (2d) 686 (I933). In Texas see Langever v. Miller, 76 S. W. (2d) I025 (Tex. Sup. Ct. I934). The New York courts have tried to avoid the question of constitutionality of the New York Act [Crv. PRACT. ACT I083-a, as amended by Laws I933 Ex. Sess. c. 794, $\$ 2$, as amended by Laws 1934, c. 562], providing for full satisfaction if no motion for entry of a deficiency judgment is made within ninety days. See New York Life Ins. Co. v. H. \& J. Guttag Corp., 265 N. Y. 292, 295, I92 N. E. 481, 482 (I934). 
ability of construction clause. ${ }^{49}$ As to pre-existing obligations, the fact that the mortgagee is forced to forego a portion of the debt of which the contract, valid when made, gave him ownership, has generally been sufficient basis for holding such statutes unconstitutional.

In some jurisdictions there has been no direct pronouncement by the highest local tribunal as to the validity of this type of legislation because of the relatively limited period for which it was declared to be effective. So, in Pennsylvania, the Act of I933, a hasty and ill-drawn measure, was replaced by a more carefully-considered statute in 1935 , before the Supreme Court had passed on the earlier act. ${ }^{50}$

By what might seem to the layman to be a curious quirk of the law, jurisdictions such as New Jersey, which have been extremely liberal in allowing judicial redefinition, have declared specific legislative attempts directed toward securing the same result, by substantially similar procedures, to be unconstitutional. Anomalous as this may appear at first glance, thoughtful. consideration of the problems faced in each instance compels the recognition that such a difference in conclusion is legally almost inevitable. The constitutional restriction that "no state shall pass any law impairing the obligation of contracts" is a rein upon legislative and not court action. It is, to be true, the modern fashion to consider constitutional law as extremely flexible, with its roots deeply imbedded in public policy, and it might be thought that the acts could easily be upheld. Such a view is justified when a novel situation arises, but in this problem a considerable body of case law is directly in point. The typical factual situation presented in a deficiency judgment question is as old as the Constitution. Precedent has clustered quickly about the bare words of the constitutional section giving it in this connection, for better or worse, a rigidity not easily overcome.

\section{Conclusion}

The aim of the law should be the establishment of a policy sufficiently elastic to be relatively permanent, which penalizes neither mortgagor nor mortgagee, but gives to each what is his due. The classic method of deficiency determination is fundamentally unsound, failing to distinguish between price and worth. Whatever justice it may achieve in a given case is not due to its intrinsic merits, but rather to the accidental correspondence of price with worth, because of the state of the times. Redefinition of deficiency as the amount remaining payable by the mortgagor after deduction of the fair value of the premises, rather than the price actually obtained at foreclosure sale, from the face of the obligation, accomplishes a nicer balance of the equities between the parties which is not disturbed by changing economic conditions. It should be recognized more clearly than it has been in the past that this is a substantive redefinition of a right, and not merely a procedural change. Legislative redefinition cannot legally surmount the constitutional obstacle against impairment of pre-existing obligations. The attention of the legislatures should be focused, then, on the application of redefinition to legally binding agreements to be entered into in the future. Judicial redefinition of deficiency, by way of refusal of confirmation unless

49. N. C. Code ANN. (1935) \$2593 (c) ; S. D. LAws 1933, c. I38. These applied specifically to mortgages to be given in the future.

50. See sispra note 25. 
the mortgagee consents to the imposition of equitable conditions, is not subject to these objections. The flexibility, feasibility, and fairness of this method make its permanent adoption advisable. The machinery of equity has been built to meet just such situations. There is no good reason why it should not be used.

$$
\text { J. M. S., Jr. }
$$

\section{Creditors' Rights in Insurance Policies during Life of the Insured}

The rise of modern commercialism has been attended with many interesting mutations in the relations between business men. The key relation of debtor and creditor, in particular, has undergone drastic modifications. No averagely alert person today will deny that the trend of modern commercial legislation and practice is toward the relief of the debtor from some of the more or less onerous obligations imposed in favor of the creditor by the older legal rules. Only a century or so ago men languished in debtors' prisons, committed at the suit of their creditors, surrounded by conditions to which the most reviled of criminals was hardly subjected, and heartened with no opportunity to do so much as work off their obligations. ${ }^{1}$ Today, legislatures attempt to raise the standard of humanitarianism by enacting liberal laws for exemptions, extensions and reorganizations.

Along with other kinds of commercial endeavor the device of insurance has also progressed; even the ordinary life insurance policy of the present day, glittering with all modern conveniences in the way of "special features", is a far cry from the original mutual agreement known to the common law. Inevitable, in connection with such a development in the merchandise, was a corresponding advancement in the rules which govern its existence. Here too, it will be seen, the tendency-in many instances the primary consideration-is to build a protective bulwark which will shield the insured and his assets from the onset of his obligees.

This note will not concern itself, except incidentally, with the status of a debtor's entire contract (policy). Its scope includes only the creditor's rights in one aspect of that contract, namely the so-called "cash surrender value". A working definition, admittedly rough but sufficient for present purposes, is as follows: The cash surrender value of an insurance policy is that portion of the money paid to the insurer by the insured which exceeds the amount necessarily expended by the insurer in financing the policy. ${ }^{2}$ Under the terms of most modern insurance policies (including the soi-disant endowment and annuity contracts-of which more later) this cash surrender value is payable to the insured on demand by him, after the policy has been in force for a stipulated period but before the maturity thereof. ${ }^{3}$ Such a potential fund of

r. Still annoying, it should be noted, is the question of whether imprisonment of a respondent for contempt of court in failing to obey an equity decree for the payment of money is in fact imprisonment for debt. For the most recent focus upon this see TIMIE, Nov. II, I935, at I2.

2. Cf. 3 Couch, Cyctopedia of Insurance LAw (1929) §647a; VANCE, Insurance (ad ed. I930) at pp. 54-56.

3. Cf. provision in standard ordinary life policy of the Equitable Life Assurance Society: "Within three months after default in the payment of any premium after two full years' premiums have been paid, the Insured may elect . . . (a) To surrender this policy 
cash, usually due absolutely and from an eminently solvent source, is too luscious a sweetmeat long to be ignored by a creditor starved by nonpayment and oftentimes temporarily frustrated by his debtor's insolvency. Consequently it is hardly surprising that its reachability by creditors of a bankrupt insured is a question frequently submitted for adjudication.

\section{LTFE PolicIes}

\section{(a) Bankruptcy}

Since all problems under this head must first be considered in the light of the Federal Bankruptcy Act, ${ }^{4}$ it may not be amiss to inquire briefly into the applicable provisions of that statute. Section $70 a$ enacts:

"That when any bankrupt shall have any insurance policy which has a cash surrender value payable to himself, his estate, or personal representatives, he may, within thirty days after the cash surrender value has been ascertained and stated to the trustee by the company issuing the same, pay or secure to the trustee the sum so ascertained and stated, and continue to hold, own, and carry such policy free from the claims of the creditors participating in the distribution of his estate under the bankruptcy proceedings, otherwise the policy shall pass to the trustee as assets." 5

This would seem to be fairly clear; but another relevant part of the Act, Section $6,{ }^{6}$ beclouds the point by providing that

"This act shall not affect the allowance to bankrupts of the exemptions which are prescribed by the State laws in force at the time of the filing of the petition. . . ."

Taken concomitantly, these provisions were originally held to compel the result that the policies passed to the trustee in bankruptcy as assets of the debtor. ${ }^{7}$ Of course it follows that if the policies are not secured to the insured, neither is the cash surrender value of those policies. The circuit court of appeals, however, reversed the district court on this score and held that Section 6 was not limited by Section 7oa, but required federal bankruptcy courts to declare exempt any policies which were so under state statutes. ${ }^{8}$ Final sanction was given this opinion when the Supreme Court ruled, in the renowned case of Holden $v$. Stratton, ${ }^{9}$ to the same effect. Subsequent cases ${ }^{10}$ in the Supreme Court seem to limit the application of this

and receive its net cash value, which shall be the cash value as determined in accordance with [an attached] table increased by the cash value of any Dividend Additions and reduced by, the amount of any indebtedness (including interest) to the Society against this policy. . . ."

4. 3o Stat. 544 (I898), iI U. S. C. A. (Ig27).

5. Id. at 566, II U. S. C. A. § II0 (I927).

6. Id. at 548 , II U. S. C. A. $\$ 24$ (I927). I899).

7. In re Lange, $9 \mathrm{I}$ Fed. 36I (N. D. Iowa 1899 ); In re Steele, 98 Fed. 78 (S. D. Iowa

8. Steele v. Buel, I04 Fed. 968 (C. C. A. 8th, I900).

9. 198 U. S. 202 (1905).

10. Burlingham v. Crouse, 228 U. S. 459 (I9I3); Cohen v. Samuels, 245 U. S. 50 (Igr7); Cohn v. Malone, 248 U. S. 450 (IgIg). 
rule, but, it is submitted, leave it substantially in full force for purposes of the present discussion. ${ }^{11}$

In view of the above rule, one is brought perforce to a contemplation of the germane legislative declarations of the various states. At last computation forty-seven states and the District of Columbia were found to have some kind of statute exempting, to a greater or less extent, the proceeds of life insurance policies from the claims of creditors. ${ }^{12}$ Hence the controverted question, What are the rights of creditors, in the absence of a statute? becomes, for the nonce at least, unimportant. ${ }^{13}$ On the other hand, an examination of the theory, phraseology and construction of the state exemption laws seems definitely in order.

As to the first point just enumerated, Judge Cooley summarizes thus: "All the statutes bearing on the exemption of life policies or their proceeds seem based on the theory that, in the absence of an expressed contrary intent, the object of an ordinary life insurance policy should be considered as the protection of the insured's family after his death, and that this object and desire is laudable and in accordance with public policy." 14 Such a statement, on its face, appears almost to approach truism; but some reflection, together

Ir. The Burlingham case held that bankrupt could keep the policies if he paid the amount of the cash surrender value to the trustee, but that if the policy had no cash surrender value, bankrupt would have the policy outright; the Cohen and Cohn cases did not consider section 6 of the Bankruptcy Act.

12. Ala. Gen. Acts Extra Sess. 1932, no. I60, p. 190; ArIz. REv. Code (Struckmeyer, 1928) \$ I738 (I3); ARK. Dig. STAT. (Castle, Supp. I93I) \& 5989a; Ark. Laws 1933, no. I02, p. 321 ; CAL. CODE CIv. Proc. (Deering, I93r) \&690 (I8); 2 Colo. ANN. STAT. (Courtright's Mills, I930) § 3592a; ConN. Gen. STAT. (Supp. I935) c. 220, § I568c; 37 Del. Laws 1931, c. 52, § 43; 48 Stat. II25, I175 (Dist. Col. 1934) ; 3 Fla. Codrp. Laws AnN. (Skillman, I928) $\$ \S 7065,7066$; Ga. Laws I933, no. 336, p. I8I; IDAHo CoDE ANN. (I932) tit. 8, $\$ 204$ (9) ; IrL. Rev. Stat. (Cahill \& Moore, r935) c. 73, I 342 ; Ind. Stat. AnN. (Baldwin, I934) \$9957; Iowa CoDE (I93I) \$8776, amended 45 Iowa Laws I933, c. I50; KaN. REv. Stat. (Supp. I93I) c. 40, \$ 4I4; Ky. Stat. (Carroll, I930) \$655; 2 LA. Gen. Stat. ANN. (Dart, 1932) § 4105, amended La. Laws 1934, no. 155, p. 520; ME. REv. STAT. (I930) c. 60, § I44; I MD. ANN. CoDE (Bagby, I924) art. $45, \S \S 8,9$, art. $48 \mathrm{~A}, \S 86 ; 2$ MASS. GEN. LAwS (I932) c. $175, \S \S 125$, I26, amended Mass. Acts I933, c. 42; 3 Mich. CoMp. LAws (I929) $\$ \S 12451$, I2452, amended Mich. Laws 1931, no. I70, p. 262; I Minn. Stat. (Mason, Ig27) $\S 3387$; I Mrss. Code (I930) $\$$ I755, 1756, I757; Miss. Laws I932, c. I38 $\$$ Io (c); I Mo. Rev. Stat. (1929) \$\$5736-5739; 3 Mont. Rev. Code (I921) $\$ 9428$ (7) ; Neb. Laws 1933, c. $73 ; 4$ Nev. Comp. Laws (Hillyer, I929) $\$ 8844$ (I4); N. H. Laws I931, c. I75; 2 N. J. Comp. Stat. (Insurance 1910) p. 2850, $\$ \$ 35,38,39$; N. M. Stat. ANn. (Courtright, I929) c. $48, \S 106 ;$ N. M. Laws 1933 , c. 67 ; N. Y. CoNs. LAws (Cahill, I930) c. $30, \$ 55 a ; \mathrm{N}$. Y. Cons. Laws (Cahill, Cum. Supp. 193I-1935) c. $30, \$ \S 55 b, 55 \mathrm{c} ;$ N. C. Coje (Michie, I935) $\$ \$ 6464,6464$ (a) ; N. C. Const. art. Io, \$ 7, app. I, p. $2632 ;$ N. D. Comp. LAws (Supp. I925) \$8718a; N. D. Laws I927, c. 225; amended N. D. Laws I929, c. I49; OHIo Code ANN. (Throckmorton's Baldwin, 1934) \$\$ 9394, 9397, 9398; 2 OKLA. STAT. (I93I) \$\$ I05I7, 10518; 3 Ore. Code ANn. (I930) tit. 46, §5I4; PA. STAt. ANN. (Purdon, I930) tit. 50, §\$ 5I4, 5I5, 5I7; PA. Stat. ANn. (Purdon, Supp. I934) tit. 40, $\$ 766 ;$ R. I. Acts and Resolves I93I, c. I757, \$§ I3, I4; 3 S. C. CTv. Code (I932) \$ 7985 [violates S. C. Const. art. III, \$ 28, and is invalid. In re Cunningham, I5 F. (2d) 700 (E. D. S. C. I926)]; I S. D. Consp. LAwS (1929) \$266I ; 2 S. D. Comp. Laws (I929) § 9310, amended S. D. Laws I931, c. I70, \$ 9310; Tenn. Code (I932) $\$ \$ 8456,8457,8458$; Tex. Stat. (I928) art. 5068a; Tex. Stat. (Supp. I93I) art. 3832a; Utah Rev. Stat. ANn. (I933) tit. I04, c. 37, \$ I3 (8); VT. Gen. Laws (I9I7) $\$ 3331,3534 ; 8$ WASH. REV. STAT. (Remington, I93I) tit. $45, \$ 7230-I$; W. VA. CoDE (I93I) c. 33 , art. $3, \S 34 ;$ W. VA. Code (I93I) c. 48 , art. $3, \$ 23$; WIs. Stat. (I93I) $\$ \$ 246.09,272.18$ (I9), amended Wis. Laws I933, c. 320, \$ x; Wyo. Rev. Stat. AnN. (I93I) art. $57, \S 236$.

13. ".. . there is no doubt that unless restrained by statute this cash surrender value is an asset available to the creditors." GLENN, CREDITORS' RIGETS AND REMEDIES (I9I5) $\S 53$, p. $4 \mathrm{r}$. Such a categorical statement may perhaps be questioned.

I4. 7 Cooley, Briefs on Insurance (2d ed. ig28) 6508. 
with recent court decisions and legislative enactments, will show that it must be strictly limited to its express words. Cash surrender value and also ultimate tontine payments collectible under endorement policies cannot validly be said to be embraced in these terms; disability benefits must not be included; dividends on policies are not within its purview; annity contracts, latest and most elusive efflorescence of the insurance business, are outside of its ambit. Furthermore, the very words must be rigidly construed: a provision for the right to receive a given cash value is plainly not an indication of a desire on the part of an insured to protect his family after his death; yet such cash value is almost universally held to be "proceeds" within the verbiage of a statute which provides in substance that the "proceeds" of life insurance policies taken out for the benefit of certain classes of beneficiaries shall be free from the claims of creditors. ${ }^{15}$ It would perhaps be more accurate to say that modern exemption statutes for the most part proceed on the even broader theory that the object of a life insurance policy is, first, the protection of insured's family after his death, and second, the security of both insured and his family during his life. In any case, however, the statutes rest on the proposition that neither a debtor nor his estate should be permitted to sustain a complete plucking at the hands of his creditors. Indubitably, of course, the plight of such a debtor's family is of ponderous import in any judicial or legislative mind.

Concerning the phraseology of the exemption laws, it may be said without exaggeration that there are practically as many variations therein as there are jurisdictions in which they prevail. It has been remarked that "There is such a lack of uniformity in the statutes relating to this subject . . . that a movement to make uniform the law . . . might be wise in the interest not only of the insurance companies, but of the business public as well." 16 Yet while this is literally true, even a cursory survey serves to demonstrate that the statutes readily divide into groups, according to their language, their viewpoint, and the kinds of situations they are designed to cover. Due to almost infinite differences in wording, the outlines of each category are, it is true, anything but distinct; there is an inescapable overrunning and diffusing from one to another. Matters are further complicated by the fact that a great majority of states has on the books several separate acts, operating concurrently, each one of which may fall into a different group from its fellows. ${ }^{17}$ But some sort of classification, however crude, is possible, and, it is believed, desirable.

The largest aggregation, represented by acts in over twenty states, is best illustrated by the New York statute. ${ }^{1 s}$ This type of act provides, in substance, that if a policy of insurance is effected by one person for the benefit of another, the "lawful beneficiary", other than the insured, shall be entitled to the "proceeds and avails" of the policy as against creditors of the

I5. Magnuson v. Wagner, I F. (2d) 99 (C. C. A. 8th, Ig24); In re Lang, 20 F. (2d) 236 (E. D. Pa. I927) $a f^{\prime} d$ sub nom. Dussoulas v. Lang, 24 F. (2d) 254 (C. C. A. 3d, Ig28); Dawson v. Nat. Life Ins. Co., I56 Tenn. 306, 300 S. W. 567 (I927). But $c f$. Morgan v. McCaffrey, 286 Fed. 922 (C. C. A. 5th, I923).

I6. Young, Bankruptcy and Exemption Statutes as Affecting Disposition of Life Insurance Proceeds (IgI8) I Procededings of tHe Assoctation of Life Insurance Counsei, no. XXIII, p. 7.

I7. See, e. g., Maryland, New Jersey and Washington, cited sitpra note I2.

I8. N. Y. Cons. LAws (Cahill, I930) c. 30, §55a. 
insured. Federal courts, administering such a statute in bankruptcy proceedings, have held that it exempts the cash surrender value of a life insurance policy. ${ }^{19}$ It will be observed that this construction in point of fact exempts to the bankrupt-only indirectly to the beneficiary; for the result of such a holding is that when the insured obtains his discharge, he is enabled to make his new start still numbering the policies among his assets. ${ }^{20}$ Subsequently he may at his pleasure maintain them as insurance on his life, proceeds to go to the named beneficiary, or surrender the policies to the insurance company in return for their cash value, or exercise any of the "options" which he may be allowed by the terms of the contracts. The rationale of most of the decisions is that the beneficiary has acquired a "vested interest" by being designated in the policy, which interest may not be interfered with by creditors of the bankrupt or by the trustee in bankruptcy acting in their behalf. $^{21}$ Whatever one may think of the cogency of such reasoning, it surely is not difficult to follow if the policy contains no clause reserving to insured the right to change the beneficiary. Actually, however, practically all modern insurance contracts do contain this kind of provision, thus casting doubt on the "vested" nature of the beneficiary's interest, and it is usually necessary to resort to some other device in order to protect the wife or family of the bankrupt. ${ }^{22}$ The obvious step has been taken: courts decide that in such a case the beneficiary's interest is not contingent, but vested at the issuance of the policy, subject to be divested by any change the insured may make in accordance with its terms. ${ }^{23}$ The general purpose, of course, is the same in either instance, and is perhaps the controlling consideration in the minds of the courts. If this is true, those tribunals which rule to the contrary when insured has reserved the "right to change" will be seen to be following the line of strict logic rather than that of social policy. Particularly notable is the fact that many legislatures, probably with the likelihood of such a decision in mind, have included in the type of statute under discussion an additional provision to the effect that the act shall operate "regardless of whether or not the insured has reserved to himself the right to change the beneficiary". ${ }^{24}$ At present the trend seems markedly in this direction. ${ }^{25}$ Meanwhile it seems safe to say that in the absence of any similar statutory benediction, the beneficiary's rights, however tenuous, will continue to receive the benison of judicial pronouncement. ${ }^{26}$

I9. In re Pfaffinger, 164 Fed. 526 (W. D. Ky. 1908); In re Messinger, 29 F. (2d) 158 (C. C. A. 2d, 1928) cert. denied sub nom. Reilly v. Messinger, 279 U. S. 855 (I929); In re Sturdevant, 29 F. (2d) 795 (W. D. N. Y. I928).

20. Cf. In re Messinger, $29 \mathrm{~F}$. (2d) I58, 160 (C. C. A. 2d, I928) cert. denied sub nom.

Reilly v. Messinger, 279 U. S. 855 (I929).

2I. The authorities are collected in VANCE, INSURANCE (2d ed. I930) pp. 54I-543.

22. For arguments that "the reservation of the right to change the beneficiary does not make the cash value payable to the insured bankrupt within the meaning of the proviso clause" of the Bankruptcy Act ( $\$ 70 a)$, see Howland, The National Bankruptcy Act as Relating to Life Insurance (I9I4) I PROCEEDINGS OF THE Assoctation OF LIFE INSURANCE Counset, no. II, pp. 8-io.

23. Cases are collected and classified in VANCE, Insurance (2d ed. I930) pp. 559-569.

24. See, e. g., 48 Stat. II25, Ir75 (Dist. Col. I934) ; 2 Mass. Gen. Laws (I932) c. I75, $\S 125 ; N$. Y. CoNs. Laws (Cahill, I930) c. $30, \S 55 \mathrm{a}$.

25. See Patten, The Effect of Insured's Bankruptcy on Policies Payable to His Wife, but Reserving the Right to Change (1929) 4 Procendings of the Assoctation of Life INSURANCE COUNSEL 259, 264.

26. See Patten, supra note 25, at 285. 
A second group of exemption statutes, not so widely distributed as the first, but nevertheless existent in some form in about ten jurisdictions, is one the constituents of which provide in effect that it shall be lawful for any married woman to insure her husband for her benefit, and if she survives said husband she shall be entitled to the proceeds of the insurance thus effected, free ard clear of the claims of creditors. ${ }^{27}$ That this kind of enactment does not protect cash values would seem too clear to admit of any controversy, since the wife's exemption is made expressly to depend on survivorship. Complications, however, are injected when, as is so often the case, a statute like the above is carried in connection with one of a third type. Type three reads approximately thus: Any policy of life insurance, or the proceeds thereof, effected for the benefit of a married woman, shall inure to her separate use and benefit, free and clear of the claims of creditors. ${ }^{28}$ The evident purpose of these statutes is the primal one of protecting the helpless surviving spouse; but here as elsewhere the development has been towards exempting the cash surrender value to the insured during his life. ${ }^{29}$ Consequently the statute is made an instrument for the immediate protection of the insured, the beneficiary (presumably insured's wife) profiting only ultimately and by indirection. The wisdom of this construction has been remarked; otherwise the statute's "failure to protect the cash surrender value-the keystone upon which the policy rests-results in there being no proceeds at death to be protected." 30 "In accord is the highly important rule, previously referred to, that "proceeds" is a word which comprises also the cash surrender value. ${ }^{31}$

Sometimes the exemption of insurance, in whole or in part, is achieved by merely appending a clause to the enumerations of the general exemption law of the particular state. This is likely to assume a form somewhat like the following: All moneys, benefits, privileges or immunities derived from life insurance on the life of the debtor are exempt, etc.; ${ }^{32}$ or perhaps, All money received by or payable to a surviving wife or child on the life of a deceased husband or father are exempt, etc. ${ }^{33}$ For the most part these provisions are quite clear as far as they go; unfortunately many of them are inadequate when applied to situations involving principles beyond the elementary. ${ }^{34}$

Of the other statutes on the subject, more or less superficially conformable to the categories above suggested, some are extremely loose, covering only a limited field; others are sweepingly absolute. An example of the former is the class which declares that the avails of life insurance policies payable to the representative or estate of the insured are not subject to the

27. See, e. g., Ill. Rev. Star. (Cahill \& Moore, r935) c. 73, $\mid$ 342.

28. See, e. g., 3 MrCH. Comp. LAws (I929) \$§ I245I, I2452; VT. Gen. Laws (IgI7) $\S \S 3531,3534$.

29. Ehrhart v. N. Y. Life Ins. Co., 45 F. (2d) 804 (S. D. I11. I929); In re Reiter, 58 F. (2d) 63I (C. C. A. 2d, 1932); In re Miller, 74 F. (2d) 86 (C. C. A. 8th, 1934).

30. Patten, sipra note 25, at 266.

3r. Magnuson v. Wagner, I F. (2d) 99 (C. C. A. 8th, I924); In re Lang, 20 F. (2d) 236 (E. D. Pa. I927) aff'd sub nom. Dussoulas v. Lang, 24 F. (2d) 254 (C. C. A. 3d, ig28); Dawson v. Nat. Life Ins. Co., 156 Tenn. 306, 300 S. W. 567 (I927), cited note I5, supra.

32. Cf. Cal. Code CIv. Proc. (Deering, I93I) \$690 (I8).

33. Cf. ARIz. REv. CODE (Struckmeyer, Ig28) \& I738 (I3).

34. See the result in In re Hammells, 5 F. (2d) 879 (D. Ariz. r925), decided under the Arizona statute cited note 33 , sipra. 
debts of decedent except by special contract; ${ }^{\mathbf{3 5}}$ typical of the latter group is that stipulating that all moneys, avails, cash surrender values and all and every benefit accruing under any policy or certificate of life insurance payable to a beneficiary other than the estate of the insured shall be exempt from garnishment, attachment, or other process and from all claims of the creditors of the insured. ${ }^{36}$ Between these two outposts are individual variations so manifold as to render their application a matter of personal interpretation. But in all cases the liberalizing bias of the courts should be kept in mind.

Federal decisions under the state exemption statutes have been legion. Where the statute has been previously construed by a state court, the federal court must naturally follow that construction; ${ }^{37}$ but where no state court has passed upon its statute, the federal court will reach an independent conclusion. $^{38}$ In such a situation it would be futile to speak of, or even to attempt a formulation of a "federal rule" and a "state rule." While each case does not require special examination, each statute probably does. One can do no more than note a crude provisional principle, a proclivity rather than a prescription. On this score it can be said that, due no doubt to forces above intimated, a construction favorable to the debtor will be adopted wherever the legislative language permits. ${ }^{39}$ A few courts adhere steadfastly to the rigid "vested-or-contingent" dogma, ${ }^{40}$ but most, while perhaps paying lip-service to time-honored concepts, manage to achieve within their bounds a result consonant with more newly evolved relations between debtor and creditor. ${ }^{41}$ Possibly the most striking characteristic of the decisions is the recency, and withal the rapidity, of the liberalizing impulse. Partially explainable by the fact that exemption statutes have become increasingly broad and frequent ${ }^{\mathbf{4 2}}$ (and such fact in itself, it is submitted, cannot be entirely due to agitation by the insurance companies), this disposition on the part of the courts has been, of late years, remarkably accelerated. What present conditions and opinions-in many instances lately revised-may produce along this line can only be surmised.

Comparatively few cases in the state courts, it is obvious, involve adjudication of creditors' rights under the Bankruptcy Act, but there are several circumstances where the question may arise. For instance, the trustee of a deceased bankrupt may bring an equitable action against the administrator; ${ }^{43}$

35. Cf. 2 N. D. Comp. Laws (1913) \$8719.

36. Cf. Neb. Laws I933, c. 73.

37. Ralph v. Cox, I F. (2d) 435 (C. C. A. 8th, 1924).

38. In re Weick, 2 F. (2d) 647 (C. C. A. 6th, I924); In re Lang, 20 F. (2d) 236 (E. D. Pa. 1927) aff'd sub nom. Dussoulas v. Lang, 24 F. (2d) 254 (C. C. A. 3d, 1928); Schwartz v. Holzman, 69 F. (2d) 814 (C. C. A. 2d, 1934).

39. See Young, loc. cit. supra note I6; Patten, loc. cit. supra note 26 ; cf. Jens v. Davis, 280 Fed. 706 (C. C. A. 8th, I922); In re Cooper's Estate, 28 F. (2d) 438 (D. Md. Ig28); In re Reiter, 58 F. (2d) 63I (C. C. A. 2d, I932); In re Phillips, 7 F. Supp. 807 (M. D. Pa. I934).

40. Mutual Benefit Life Ins. Co. v. Swett, 222 Fed. 200 (C. C. A. 6th, 1915); Whiting v. Squires, 6 F. (2d) roo (C. C. A. 4th, I925).

4I. Brown v. Home Life Ins. Co., 3 F. (2d) 66I (E. D. Okla. I925); see In re American Range \& Foundry Co., I4 F. (2d) 308, 3 II (D. Minn. I926). For avowedly "liberal" constructions, see Hickman v. Hanover, 33 F. (2d) 873 (C. C. A. 4th, 1929) ; In re Horwitz, 3 F. Supp. I6 (W. D. N. Y. I933).

42. See Pierson, Recent Legislation. Preserving Insurance Proceeds for Beneficiaries (I930) I6 A. B. A. J. 23.

43. Dreyfus v. Barton, 98 Miss. 758,54 So. 254 (IgII). 
or the beneficiary may attempt to replevy the policy from the trustee. ${ }^{44}$ It is interesting to note that where the state courts have had an opportunity to construe their own exemption laws, they have generally, if not always, favored the insured or his beneficiary over the trustee. ${ }^{45}$ Possible significance of this, however, is weakened by the paucity in the number of cases actually decided on that point.

A companion problem, in the administration of the Bankruptcy Act, to that of exemption statutes is one relating to the insured's right to exercise his options under the policy. Modern policies frequently provide for the election, at insured's will, of any one of numerous conveniences offered him by the company. He may be given the right at any time to surrender the policy in exchange for its then cash value; he may be allowed to cease paying premiums, surrender the policy, and demand that the then surrender value be applied by the company to paid-up insurance for a reduced amount; he may, in the case of an endowment policy, be permitted to leave the matured endowment deposited with the company and receive in return a policy paid up to the amount of said endowment; or he may be suffered to take advantage of any of the apparently innumerable devices springing from the ingenious minds of those who write contracts of insurance. ${ }^{46}$ Should one of these options lie within the power of insured, a trustee might well contend that under Section 7oa of the Bankruptcy Act, above set out, ${ }^{47}$ he would be entitled to exercise this option for the benefit of creditors. ${ }^{48}$ State exemption statutes condition the trustee's privilege in that regard, ${ }^{40}$ as also do other considerations of the forum, such as garnishment and attachment laws, and the like. The cases turn predominantly about the first-mentioned privilege, that of surrendering the policy for its cash value; and here at least formulation of a general rule seems to be feasible. One textwriter has stated, ". the policy is not to be regarded as liable to seizure under any form of judicial

44. Allen v. Central Wisconsin Trust Co., I43 Wis. 38r, I27 N. W. 1003 (1910).

45. Young v. Thomason, I79 Ala. 454, 60 So. 272 (I9I2); Murphy v. Casey, I50 Minn. $107, I_{4}$ N. W. 783 (I92I); Dawsonl v. Nat. Life Ins. Co., I56 Tenn. 306, 300 S. W. 567 (Ig27); Cannon v. Lincoln Nat. Life Ins. Co., 208 Wis. 452, 243 N. W. 320 (1932). See Patten, loc. cit. supra notes 25, 26; Israel, Exemption of Life Insurance Policies in New Jersey (1930) 7 A. B. REv. 76; Grade, Exemption of Life Insurance Policies under Tennessee Statutes and in Bankmptcy (I933) II TENN. L. Rev. 84; Note (I934) 8 Tulane L. REv. $45 \mathrm{I}$.

46. $C f$. the provisions of standard ordinary life policies of the Equitable Life Assurance Society, which permit insured to elect, on default (a) to receive net cash surrender value of the policy; "(b) To continue this policy as non-participating paid-up life insurance, payable at the time and on the conditions provided in this policy, for such an amount as the cash value determined in accordance with [an attached] table reduced by the amount of any indebtedness (including interest) to the Society against this policy will purchase as a net single premium at the Insured's attained age, to which amount shall be added the amount of any Dividend Additions; or (c) To continue the insurance as non-participating paid-up extended term insurance for the face amount of this policy plus the amount of any Dividend Additions and less the amount of any indebtedness (including interest) to the Society against this policy, and for such period from the due date of the premium in default as the net cash value of this policy . . . will purchase as a net single premium at the Insured's attained age."

Furthermore, under this policy "The Insured may elect ... to have the net sum due under this policy upon it maturity applied under one . . . of the following optional modes of settlement in lieu of a single sum settlement. . . . I. Deposit Option. . . 2. Insta1ment Option: Fixed Period. . . 3. Life Income Option. . . 4. Instalment Option: Fixed Amount. . . ."

47. Supra, p. 237.

48. Cf. Blinn v. Dame, 207 Mass. I59, 93 N. E. 6or (I9II).

49. Holden v. Stratton, I98 U. S. 202 (1905). 
process against the insured so long as the duty of the insurer to pay is subject to any contingency, or to any condition precedent," 50 and this is substantiated by a preponderance of the decided cases. ${ }^{51}$ But the same author's later pronouncement, that "where the only condition to the insurer's promise to pay an agreed surrender value is the insured's giving up the policy for cancellation, the courts generally permit the attaching creditor to deliver up the policy and receive the surrender value," 52 is, in the light of case authority, open to some doubt. As a matter of actuality, the courts hold fairly uniformly that the right of election is one personal to and "vested in" the insured, and no one but he may exercise it. ${ }^{53}$ On the whole, it appears that here again the question, one largely dependent on personal opinion, is subject to be resolved either way. The result reached by a majority of the courts is compatible with the penchant, already indicated, for befriending the debtor.

\section{(b) Creditors' Remedies Outside of Bankruptcy}

Attachment and garnishment are the principal bases of creditors' remedies outside of the provisions of the Bankruptcy Act. It has been further stated that "under some circumstances, a creditor may reach the proceeds of a policy during the lifetime of the insured by a creditor's bill." ${ }_{54}$ On the last point respectable case authority is wanting, and indeed it seems difficult to imagine how such a bill could be maintained (insurance policies being circumvallated by law as they now are) in the absence of fraud on the part of the insured. ${ }^{55}$ As to attachment and garnishment processes, it is practically platitudinous to remark that they are unavailable unless and until there is a "debt due" from the garnishee or whomever occupies a cognate position. The inquiry thus narrows to, When is the debt in fact due? And the courts, as before intimated, have answered almost unanimotusly, Not until the insured has exercised his rights under the policy; a court of equity cannot compel him to do so, and will not render a decree which purports to do so for him. ${ }^{56}$ Of course, if insured once makes his election, the debt of the company becomes due as of that moment, and may then be garnished or reached by attachment. ${ }^{57}$ Should the cash value be already paid to insured, an a fortiori case is presented. ${ }^{58}$ It happens in these situations that syllogistic reasoning gives results in accordance with what has been the definite drift of decision; hence statutes on the subject would not seem necessary, nor is there much probability that, without a complete judicial reaction, this form of ratiocination will be abandoned.

Of considerably more than casual interest, however, is the question raised by two recent cases in the federal district courts. ${ }^{59}$ The facts in each

50. Vance, Insurance ( $2 d$ ed. I930) \$ I6I.

5I. See Note (Ig26) 44 A. L. R. Ir88.

52. VANCE, INSURANCE ( 2 d ed. I930) §I6I.

53. See Note (I928) 57 A. L. R. 695.

54. 8 Couch, CyClopedia OF INSURANCE LaW (I93I) \$ 1932.

55. Cf. Murphy v. Casey, I50 Minn. I07, I84 N. W. 783 (I92I).

56. Farmers \& Merchants Bank v. Nat. Life Ins. Co., I61 Ga. 793, I3I S. E. 902 ( 1926); Columbia Bank v. Equitable Life Ass. Society, 79 App. Div. 6or, 80 N. Y. Supp. 428 (Ist Dep't, I903) ; Martin v. Balis, I8 D. \& C. I87 (Pa. I932).

57. Cooper v. West, I73 Ky. 289, I90 S. W. I085 (I9I7).

58. In the analogous case of dividends (New York Plumbers' Specialties Co. v. Stein, I36 Misc. 703, 240 N. Y. Supp. 834 [N. Y. City Cts. I930]) see Martin v. Balis, r8 D. \& C. 187 ( $\mathrm{Pa} . \mathrm{I932}^{2}$.

59. McGuirk v. Kyle, Io F. Supp. 705 (E. D. Pa. I935); Cannon v. Nicholas, Io F. Supp. 718 (D. Colo. I935). Both are noted elsewhere in this issue, p. 262 . 
were substantially identical. Insured was insolvent. The federal government, being a creditor for back taxes, garnisheed the insurance company. Insured contended the state exemption statute applied to the cash surrender value of his policies, that the beneficiary thereof had acquired vested rights therein, and that consequently the attachments were invalid. One court decided that the state statute was one of "exemption" only; that it could not prevail over the mandate of the federal statute which authorized attachments in situations like that under notice; and that therefore the attachment was regular and effective. ${ }^{60}$ The other court held that the state law created a "property right" in the beneficiary, not a mere privilege in the insured; that no act of Congress could constitutionally deprive the beneficiary of that right; and that therefore the attachment was void. ${ }^{61}$ The two decisions seem totally irreconcilable. But aside from this, the question itself is not only novel but significant; it offers a picture, in strongly contrasted colors, of the rights of the most powerful creditors' force-the government of the United Stateson the one hand, and the stronghold of judicial protection of the beneficiary (and, incidentally, the insured) on the other. The outcome can scarcely be adumbrated; but the decision in favor of the insured shows to what extent a sympathetic court will proceed in statutory construction where such is necessary to defend the inviolability of cash surrender values.

\section{ENDOWMENT PoLICIES.}

Endowment policies, roughly speaking, are those in which it is provided that insured, on paying premiums over a certain period of years (during which time the policy is in force as life insurance, payable to a designated beneficiary in the event of insured's decease) will receive the face value of the policy in cash at the end of the specified (so-called "tontine") period. ${ }^{62}$ This outlandish contract was, and to a certain degree still is, the foundation of much conflict. Many earlier statutes confined their exemption provisions to "life insurance," in which event it occasionally became necessary to pass upon the question whether an endowment policy was "life insurance" within the purview of the statute. Originally the theory advanced, and finally adopted by a majority of state courts, was that the contract was one primarily of investment and only incidentally of insurance. ${ }^{63}$ The leading case on this side of the argument ${ }^{64}$ contained in the opinion both the theory just set forth and the additional one that "the transaction partakes more of the character of a loan . . . [and] the money so invested belongs to the debtor; . . . the mere act of filtering it thru the insurance company will not transmute it so it becomes the property of the beneficiary. . . " 65 Becoming widely accepted, the above arguments long retained their strength so that at least one author felt constrained to say, in I92I, "It is well settled that endowment policies . . . pass to the trustee in bankruptcy to the extent of their cash surrender value." ${ }^{66}$ Yet the same author, eight years later,

6o. Cannon v. Nicholas, supra note 59.

61. McGuirk v. Kyle, supra note 59.

62. Cf. Talcott v. Field, 34 Neb. 6II, 6I4, 6I5, 52 N. W. 400,401 (I892).

63. Note (Ig06) 4 L. R. A. (N. S.) 456 ; VANCE, INSURANCE (2d ed. I930) p. 548.

64. Talcott v. Field, 34 Neb. 6II, 52 N. W. 400 (I892).

65. Id. at $6 \mathrm{I}_{4}, 52 \mathrm{~N}$. W, at $40 \mathrm{I}$.

66. Patten, Do General State Exemption Statutes in Favor of Insured's Wife Protect "Right to Change" Policies Payable to Her, Containing No Endowment Feature, From His Trustee in Bankruptcy? (I921) I ProceEdings of the Association of Life Insurance COUNSEI, no. III, at p. I8. 
considered it equally incumbent to remark: "I now think . . . endowment policies . . . should be considered as on the same footing with straight life policies in the matter of exemption." 67 Both statements were on the whole justified, even when regarded outside of the field to which they were directly applicable-bankruptcy. What theory on the other side was so compelling as to cause a small revolution in the law? One of the earliest and fullest expositions can be read in the California case of Briggs $v$. McCullough, ${ }^{\natural 8}$ where it is said, in part: "The term 'life insurance' is not alone applicable to an insurance for the full term of one's life. On the contrary, it may be for a term of years, or until the assured shall arrive at a certain age. It is simply an undertaking on the part of the insurer that either at the death of the assured, whenever that event may occur, or on his death, if it shall happen within a specified term, or before attaining a certain age, as the case may be, there shall be paid a stipulated sum. In either form it is, strictly speaking, an insurance on the life of the party." ${ }^{69}$ Although the argument that endowment policies are life policies because they relate to the tenure of life of the insured ${ }^{70}$ may not address itself so forcefully to the ears of 1935 , the present majority view, grounded upon that argument, is to the same effect. ${ }^{71}$ Again one is obliged to conclude that not the unassailability of the logic but the progressing notions of the courts and the public in general have engendered this development. Another indication of the truth of the last statement is the regularity with which exemption statutes in relatively recent years have expressly included endowment insurance in their protective embrace. ${ }^{72}$

\section{Accident and Disability Policies}

All of the Protean forms an insurance policy can-and does-assume are manifestly not within the periphery of this note. The large body of law, both judicial and statutory, on the subject of group insurance has not been consulted; the same is true of workmen's compensation and other forms of industrial insurance; fire, theft and kindred aspects of the insurance contract are palpably foreign to the topic in hand; and the constituent elements of the above heading might likewise well be divorced from the present discussion. A brief reference is made to them solely to demonstrate further the inclination of the law. Accident policies are clearly related in some way to life insurance; the doubtful ingredient is the degree of consanguinity. Disability benefits are just as clearly unrelated, or are at least mere affines. In the former there are quite as many provisions in pure self-interest as there are for the protection of the insured's family; in the latter this protection is reduced to the veriest cobweb. Yet state legislatures persistently enact laws which exempt the avails of such policies from the claims of creditors. The one state which makes no provision whatsoever for the exemption of life insurance has nevertheless a statute specifically exempting weekly or monthly installment payments to the holder of a policy of accident insurance,

67. Patten, The Effect of Insured's Bankruptcy on Policies Payable to His Wife, but Reserving the Right to Change (I929) 4 PROCEeDINGS of THE Assoctation OF LIFE INSURANCE COUNSEI, 259, 285 .

68. $36 \mathrm{Cal} .542$ (1869).

69. Id. at 550 .

70. Flood v. Libby, 38 Wash. 366,80 Pac. 533 (1905).

7 r. VANCE, INSURANCE (2d ed. I930) p. 547. Contra: In re Young, 208 Fed. 373 (N. D. Ohio I9I2).

72. See, e. g., Iowa Code (193I) §8776; ME. Rev. Stat. (1930) c. 60, § I44; 2 S. D. Comp. Laws (I929) § 9310. 
or the like. ${ }^{73}$ Seven other jurisdictions exhibit laws more or less dispositive of the subject. ${ }^{74}$ And it is to be expected that others will follow, for many of the foregoing acts are comparatively recent of promulgation. The ultimate result is well exemplified in a line of cases under the former New York statute. ${ }^{75}$ A lower court, apparently acute to the prevailing sentiment concerning insurance benefits in general, ruled that disability payments were tantamount, in legal contemplation, to cash surrender values. ${ }^{76}$ This was affirmed without opinion in the Appellate Division. ${ }^{77}$ Shortly afterwards another trial court held disability benefits not exempt under the same statute, ${ }^{78}$ and the same volume of reports contains yet another case disallowing exemption. ${ }^{79}$ With the law in this condition, a federal district court likewise refused to protect disability doles. ${ }^{80}$ The Gordian knot was cut by the legislature's passing a new section to the Insurance Law expressly exempting these payments. ${ }^{81}$ It is submitted that the explanation lies not in the desire to safeguard a forlorn widow and helpless children, but in a growing sensitivity to the readjustment in the relations between debtor and creditor.

\section{AnNuities}

By far the most youthful venture of the resourceful insurance companies is the annuity contract. This kind of "insurance" involves, in the typical instance, a lump sum paid to the company, which engages in return to deal out to the payor or to a beneficiary indicated by him a definite sum annually during the life of the annuitant. ${ }^{82}$ Once more, however, there are ingenious variations very nearly infinite; a good many modern annuity contracts, for example, provide for payments by annuitant (suspiciously resembling "premiums") during a certain period and thereafter payments by the grantor during annuitant's life. ${ }^{83}$ These contracts in turn are capable

73. VA. CODE ANN. (Michie, I930) § 4219.

74. Ark. Laws I933, no. I02, p. 321 ; 48 STAt. Ir25, II75 (Dist. Col. I934); Iowa Code (I93I) § 8776; 2 La. Gen. STAT. AnN. (Dart, I932) \$ 4105; Neb. Laws 1933, c. 73; N. Y. Cons. Laws (Cahill, Cum. Supp. I93I-I935) c. 30, § 55b; Pa. Stat. Ann. (Purdon, Supp. I934) tit. $40, \$ 766$.

75. N. Y. Cons. Laws (Cahill, I930) c. 30, $\$ 55 a$.

76. Wittman v. Littlefield, I42 Misc. 9r6, 256 N. Y. Supp. 47 (Sup. Ct. 1932).

77. Wittman v. Littlefield, 235 App. Div. 83I, 257 N. Y. Supp. 885 (Ist Dep't 1932).

78. Herbach v. Herbach, I48 Misc. 33, 265 N. Y. Supp. I44 (N. Y. City Cts. I933). 1932 ).

79. Lion Credit Union v. Gutman, I48 Misc. 620,265 N. Y. Supp. 479 (N. Y. City Cts.

8o. In re Kern, 8 F. Supp. 246 (S. D. N. Y. 1934).

8I. N. Y. Cons. Laws (Cahill, Cum. Supp. I93I-1935) c. 30, $\$ 55 \mathrm{~b}$.

82. Cf. I Couch, Cyctopedia of Insurance Law (1929) \$25; People ex rel. Metropolitan Life Ins. Co. v. Knapp, I93 App. Div. 4I3, 4I5, I84 N. Y. Supp. 345, 346 (3d Dep't I920).

83. See, for example, the standard annual payment retirement annuity of the Equitable Life Assurance Society, which provides that the Society "Hereby agrees to pay a life annuity to.$\ldots \ldots \ldots \ldots \ldots$ subject to the conditions hereinafter stated, in monthly payments of ......... Dollars, beginning on the anniversary of the Register date of this contract upon which the Annuitant's age at nearest birthday is ....... years . . . but at any time prior to commencement of such Annuity payments on said date the Annuitant may ... . elect . . in lieu thereof either: (I) A Life Annuity beginning at any age shown [in a table elsewhere in the contract] with monthly payments of the respective amounts provided in [an attached schedule], or (2) A Ten Years Certain Life Annuity beginning at any age shown in said Table. . . with monthly payments [according to a second schedule attached]."

Certain "options" are also included; $e . g$., that of receiving the surrender value within three months after default, and that of continuing the contract as a paid-up annuity, under similar circumstances. 
of subdivision into ( $\mathrm{x}$ ) those providing that payments by the grantor shall cease absolutely at the death of annuitant, regardless of when it shall occur and of how much return there has actually been on the original capital paid in by annuitant, and (2) those providing for payment on annuitant's death over to a named beneficiary of any moneys still in reserve. From even a superficial scrutiny of such contracts it should appear that protection of his family as such is almost the last thing in the annuitant's mind, unless he effects the annuity exclusively for the benefit of a wife, child, etc.-which, it may be added, is comparatively rare in annuities taken out during the last few years, the time of the ascendency of these forms of insurance. While the case authority is as yet meagre, some definite trend can be read therefrom and from pertinent legislation. Statutes imposing taxes on "policies" or "gross premiums" issued or collected by "insurance corporations" have been held not to apply to annuities; ${ }^{84}$ a recent Oregon case decided that a statute forbidding the issuance of life insurance policies until a form thereof had been filed with the state insurance commissioner did not comprehend annuity contracts in its intendment. ${ }^{85}$ Admittedly these cases have but scratched the surface; none can be said to hold that an annuity is exempt from claims of creditors, either of its own force or by virtue of a statute exempting life insurance and endowment policies. ${ }^{86}$ On the other hand, one is again faced with a statutory development leaning toward express exemption of annuities. ${ }^{87}$ And the point is further clinched by a recent case in the Circuit Court of Appeals for the Third Circuit, ${ }^{88}$ which might profitably be here set out in some detail. The contract in question, a "single premium retirement annuity," stipulated for monthly payments to annuitant at age 65 and thereafter. It contained provisions for a cash surrender value and it reserved to annuitant the right to change the beneficiary. It stated, moreover, that if annuitant were to die before the first payment by the company (grantor) his wife should receive the payments according to a schedule therein incorporated; furthermore, that if annuitant should die without leaving any designated beneficiary living, the payments were to be made to annuitant's children, or, failing any issue surviving, to his executors or administrators. The relevant (Pennsylvania) statute exempted "The net amount payable under any .. . annuity contract upon the life of any person, . . . made for the benefit of ... the wife or children or dependent relative of such person." 89 Analogizing from the rules concerning endowment policies, the court held the above annuity contract exempt under the statute. In the opinion appears this statement: "We think it clear that

84. Mutual Benefit Life Ins. Co. v. Commonwealth, 227 Mass. 63, II6 N. E. 469 (I9I7); People $e x$ rel. Metropolitan Life Ins. Co. v. Knapp, I93 App. Div. 4r3, 184 N. Y. Supp. 345 (3d Dep't 1920) aff'd 23I N. Y. 630, I32 N. E. 916 (I92I); Commonwealth v. Metropolitan Life Ins. Co., $254 \mathrm{~Pa}$. 510 , 98 Atl. 1072 (I916).

85. Hall v. Metropolitan Life Ins. Co., I46 Ore. 32, 28 P. (2d) 875 (1934).

86. But $c f$. People v. Security Life Ins. \& Annuity Co., 78 N. Y. II4 (I879).

87. See, e. g., Ga. Laws I933, no. 336, p. I8I; 2 LA. GEN. StAt. ANN. (Dart, I932) \$ 4105, amended La. Laws I934, no. I55; ME. Rev. StAT. (I930) c. 60, § I44; Neb. Laws I933, c. 73 ; N. Y. Cons. Laws (Cahill, Cum. Supp. I93I-I935) c. 30, § 55c; OHIo CoDE ANN. (Throckmorton's Baldwin, 1934) \$9394; PA. Stat. ANN. (Purdon, I930) tit. 40, $\$ \S 515,517$; TENN. CoDe (1932) \$ 8458; Tex. Stat. (1928) art. 5068a.

88. Bowers v. Reinhard, 78 F. (2d) 776 (C. C. A. 3d, I935) cert. denied sub nom.

Reinhard v. Bowers, Nov. II, I935, U. S. L. Week, Nov. I2, I935, at 45.

89. Pa. Stat. ANn. (Purdon, I930) tit. 40, \$ 517. 
where, as in this case, the wife is named beneficiary, the contract is 'made for the benefit' of the wife." ${ }^{90}$ Notable here is the same kind of reasoning that was seen in the cases involving endowment policies; it is suggested that this is a sufficient foreshadowing of the final judicial word on the subject of exemption of annuities. If this prognostication prove correct, another important wing will have been added to the legal sanctuary which, in protecting insurance contracts by exemption to the insured, simultaneously aids in sheltering the modern Antonio from the too-importunate demands of a twentieth-century Shylock.

$$
\text { B. } W . L \text {. }
$$

90. Bowers v. Reinhard, 78 F. (2d) 776,777 (C. C. A. 3d, 1935). 